\title{
Az FDI szerepe a gazdasági növekedés és a beruházások területi differenciálódásában Magyarországon
}

\begin{abstract}
A kelet-közép-európai országokban a gazdasági szerkezet átalakítása elsősorban a külföldi müködőtőke-befektetéseken (FDI) alapuló fejlesztési utat követte, amely rövid távon hozzájárult a termelékenység és a versenyképesség javulásához. A kutatás alaphipotézise szerint a dominánsan külföldi müködőtőkére építő, beruházásvezérelt kelet-közép-európai transzformációs modellben az FDI pozitív hatásai mind a beruházások, mind pedig a gazdasági növekedés tekintetében hosszabb távon sokkal kevésbé érvényesülnek. Kiindulópontunk Lengyel-Varga [2018] azon megállapítása, hogy a feldolgozóipari, külföldi müködőtőkét vonzó térségek húzzák az ország GDP-növekedését. A tanulmányban az FDI növekedésgeneráló, illetve beruházási hatását vizsgáljuk, és keressük a változók közötti oksági kapcsolatot a magyarországi megyékben. Ökonometriai elemzésünk alapján nem támasztható alá, hogy az FDI-befektetések okoznák a GDP növekedését, ugyanakkor leginkább a fejlettebb és hosszabb távon magasabb gazdasági növekedést mutató megyékbe áramlik több külföldi müködőtőke. A beruházások modellbeli szerepeltetése szintén eltünteti az FDI szignifikáns pozitív hatását. A kormányzati és EU-forrás alapú beruházások jóval nagyobb szerepet játszanak a GDP alakításában, mint a külföldi müködőtőke.*

Journal of Economic Literature (JEL) kód: E22, F21, O47, P2, R10, R11.
\end{abstract}

A külföldi müködőtőkebe-fektetések (FDI) fogadó gazdaságra gyakorolt hatását számos kutatás vizsgálta. A fóáramú gazdasági elméletek és a politikai döntéshozók gyakran hangsúlyozzák az FDI feltételezett előnyeit, de az empirikus bizonyítékok kevésbé bőségesek e tekintetben. A legtöbb tanulmány a külföldi müködőtőkének a fejlődő gazdaságokra gyakorolt hatását elemezte, ugyanakkor a működőtőke elsősorban a fejlett országokba áramlik (Lucas [1990], Gourinchas-Jeanne [2013]). A fejlett

* A tanulmány a K-120007. számú projekt keretében a Nemzeti Kutatási, Fejlesztési és Innovációs Alapból biztosított támogatással, a K_16 pályázati program finanszírozásában valósult meg. A módszertani elemzésben Gyimesi András PhD-hallgató (PTE KTK) működött közre.

Gál Zoltán a földrajztudomány kandidátusa, tudományos főmunkatárs, egyetemi tanár, RKK Dunántúli Tudományos Osztálya (e-mail: gal@rkk.hu).

A kézirat első változata 2019. május 21-én érkezett szerkesztőségünkbe.

DOI: http://dx.doi.org/10.18414/KSZ.2019.6.653 
országokat vizsgáló makrogazdasági elemzések között is jó néhány hagsúlyozza a közvetlen tőkebefektetések negatív hatását a növekedésre (Mencinger [2003], CarkovicLevine [2005], Johnson [2006], Turkcan és szerzőtársai [2008], Herzer [2012]), vagy ez a hatás nem egyértelmü (De Mello [1999]). Ezzel szemben más fejlett és fejlődő országot vizsgáló tanulmányok szerint az FDI-beáramlás pozitív hatást gyakorol (Olofsdotter [1998], Reisen-Soto [2001]), bár ezek országonként eltérők, és a szerzők a befogadó országok gazdasági környezetének, pénzügyi piaci fejlettségének fontosságát hangsúlyozzák (Alfaro és szerzőtársai [2004], Batten-Vo [2009]).

Prasad és szerzőtársai [2008] szerint a külső tőkeforrásokra támaszkodó fejődő országok lassabban növekednek, mint a saját megtakarításaikra támaszkodók. Azon feltörekvő országok növekedése gyorsabb, amelyek beruházási rátája nagyobb, és kevésbé támaszkodik a külföldi tőkére. A külföldi tőke tehát negatívan hat a növekedésre a kevésbé fejlett piacokon. Ugyanakkor a szerzők szerint a fejlett ipari országok nagyobb fizetésimérleg-hiány mellett is képesek növekedni. Ugyanakkor azt állítják, hogy a kelet-európai átmeneti gazdaságok feltehetően a fejlett ipari országokhoz hasonlítanak: azaz fizetésimérleg-hiányuk (külföldi tőkeimport) ellenére is képesek növekedni, esetükben a fizetésimérleg-hiány pozitívan korrelál a növekedéssel, tehát a beáramló külföldi tőke növekedést generál.

Úgy tủnik, hogy az empirikus irodalom egyetért azzal, hogy az FDI bármely pozitív hatása a növekedésre a fejlett országokban a legnagyobb, mivel azok képesek a külföldi befektetések hasznát learatni. Korábbi vizsgálatunk középpontjában a kelet-középeurópai átmeneti gazdaságok (V4) álltak (Gál-Schmidt [2017]). Jelen tanulmány kiindulópontja Lengyel-Varga [2018] vizsgálata, amely a nemzetgazdasági növekedést a szubnacionális térségek növekedéséből vezeti le. Kutatásunk fö kérdése tehát:

- a kelet-közép-európai átmeneti (transition) gazdaságokba beáramló külföldi működőtőkének van-e közvetlen növekedésgeneráló hatása;

- ez a növekedésgeneráló hatás vizsgálható-e területi szinten is? Ezért az FDI és a gazdasági növekedés, illetve a beruházások és az FDI közötti kapcsolat relevanciáját elemezzük a magyarországi megyék esetében.

A külföldi működőtőke-befektetések kiemelkedő jelentőségűek a kelet-közép-európai országokban, így Magyarországon is. Az utóbbi 20-25 évben jelentősen nőttek a régió minden országában, és a tőkeáramlások legfontosabb eszköztípusaivá váltak. A külföldi müködőtőke jelentős szerepet játszott a privatizációban, és az átalakulás első szakaszában a legfontosabb tőkebefektetési formát jelentette (Kalotay [2010]). A müködőtőke felgyorsította a privatizációt, és így az állami tulajdon lebontásához járult hozzá, segítette a szerkezetváltást és a piacgazdaság megteremtését, ugyanakkor egyes ágazatokban a külföldi tulajdon dominánssá válásához is vezetett. Az átmeneti gazdaságok közül a visegrádi országokban az ipari és szolgáltatási kulcságazatokban az 1990-es évek végére meghatározóvá vált a külföldi tulajdon (Gál [2013], Buch és szerzőtársai [2003]). Jelentős strukturális változásként értékelhető, hogy amíg az 1990es években a külföldi müködőtőke döntően a (feldolgozó-) iparba érkezett, addig az ezredfordulót követően - a globális trendeknek megfelelöen - Kelet-Közép-Európában is egyre nagyobb szerepet kaptak a szolgáltató ágazatok (Gál [2014]). 
Az FDI regionális hatásait elemző munkák döntően a beáramló müködőtőke pozitív hatásait emelik ki: a foglalkoztatási, a technológiai átgyürüző (spillover), valamint a termelékenységnövelő hatást (Cooke [2002]). Az új regionalizmus az FDI pozitív térségfejlesztő szerepét hangsúlyozta. A külföldi müködőtőke beágyazottsága kapcsán a regionális kapcsolatok vizsgálata, valamint a külföldi befektetők és a helyi beszállítók hálózati kapcsolatainak kialakítása is figyelmet kapott (McCann [1997], Jones-Wren [2016]). A regionális tudásgazdaság szakirodalmában - különösen a kevésbé fejlett régiókban - az FDI tudásközvetítő szerepe hangsúlyos. Lengyel-Varga [2018] a magyar gazdasági növekedés területi tényezőit vizsgálva arra a megállapításra jutott, hogy a feldolgozóipari külföldi müködőtőkét vonzó térségek húzzák az ország GDP-növekedését.

Ez utóbbi megállapítás által inspirálva jelen tanulmány célja a külföldi müködötőkének a gazdasági növekedésre és a bruttó állóeszköz-felhalmozásra gyakorolt hatásának elemzése szubnacionális szinten, a magyarországi megyékben. Megvizsgáljuk, hogy milyen összefüggés figyelhető meg az FDI és a gazdasági növekedés között regionális szinten. Feltételezhető, hogy területi szinten a megyék fejlettsége és külföldi működőtőkével való ellátottságuk közti összefüggés csupán látszólagos. Éppen ezért az FDI és a gazdasági növekedés, illetve az FDI és a beruházások közötti oksági kapcsolatot teszteljük megyei szinten.

A tanulmány felépítése a következő: az alábbi fejezet áttekinti a külföldi működőtőkéhez kötődő növekedéselméleteket, kitérve a regionális fejlődésre gyakorolt hatásokra. Ezt követően a kelet-közép-európai régióban meghatározó, FDI-vezérelt növekedési és gazdaságpolitikai modell problematikáját tekintjük át, illusztrálva a visegrádi országokból vett statisztikai példákkal. Az ez után következő empirikus fejezet a magyarországi megyékben a külföldi müködőtőke hatását vizsgálja a gazdasági növekedésre és a beruházásokra ökonometriai elemzéssel (Granger-teszt, OLS-regresszió). Az összegzés az elemzésen túlmutató növekedéselméleti problémákra is felhívja a figyelmet.

\section{Az FDI és a növekedés közötti kapcsolat}

Harrod [1939] és Domar [1947] növekedési modelljében a megtakarítások kulcsfontosságúak a tőke felhalmozódása szempontjából. Rostow [1959] bizonyítja, hogy a megtakarítások elengedhetetlen feltételei a fejlődésnek. Mivel a megtakarítási ráta - különösen a fejlődő országok esetében - jóval alacsonyabb rövid távon, ezért a külföldröl történő tőkebevonás - hitelek, portfólióbefektetések és FDI formájában pótolhatja a hazai megtakarítások hiányát. Azok a kormányok, amelyek a növekedés fokozására törekedtek, adókedvezmények és támogatások révén versenyeztek a külföldi müködőtőkéért. Ugyanakkor jó néhány fejlődő ország függő helyzetbe került a müködőtőke-befektetések révén, illetve jelentős a profitkivonás kockázata, ami egy idő után jóval meghaladhatja az újra befektetett tőke értékét (lásd Hughes [1979], Dixon-Boswell [1996], Kentor [1998]). Herzer és szerzötársai [2014] a fejlődő 
országokban az egyenlőtlenség jelentős növekedését mutatta ki, s vizsgálatuk szerint az FDI az egyenlőtlenség legfőbb okozója.

A neoklasszikus növekedési elmélet szerint (Solow [1957]) a tőke a fejlett országokból a fejlődő országokba áramlik, mivel a tőkehiány miatt feltételezhető, hogy a tőkehozamnak magasabbnak kell lennie a fejlődő országokban, ezzel a nemzetközi tőkét a szegényebb országokba csábítva, így elősegítik hosszabb távon a tőke és a hozamok kiegyenlítődését. Ez elméleti támogatást nyújtott a fejlődő országokba érkező külföldi befektetések, köztük az FDI ösztönzésére. Ugyanakkor az empirikus bizonyítékok azt sugallták, hogy a növekedés hosszú távon a technikai fejlődés, nem pedig a tőkebefektetések következménye (Solow [1957]). Ráadásul a Lucas-paradoxonnak nevezett elmélet bizonyította, hogy a tőke nem a gazdagokból a szegény országokba, hanem éppen fordítva, a fejlődő országokból a fejlettekbe áramlik (például Lucas [1990], Gourinchas-Jeanne [2013]). Feldstein-Horioka [1980] szerint a tőke - a hasonló hozamok ellenére is - elsősorban a fejlett országok között áramlik, és továbbra is a fejlett országokba irányuló tőkeáramlás dominál. A tökéletes nemzetközi tőkemobilitás elméletét cáfoló érvelés szerint a hazai megtakarítások és a hazai beruházások között erős a korreláció, azaz a megtakarítók megtakarításaik többségét helyben, a származási országban fektetik be, s nem külföldre helyezik ki (Gál [2015]). Rácáfolva ezzel a standard elméletekre, a hazai befektetések és megtakarítások között tehát továbbra is erős a korreláció (Gál [2010], [2015]).

Az exogén növekedési elméletek az FDI által közvetített technológiatranszfer növekedésben játszott szerepét hangsúlyozzák (Solow [1957], Blomström és szerzőtársai [1994], Blomström-Kokko [1998]). Ezzel szemben az endogén növekedés elmélete a hazai technológia szerepét hangsúlyozza a termelékenység növelésében, amit az FDI is közvetíthet más országokba (Lucas [1988], Romer [1990]). Ugyanakkor a technológiaimport növekedésgeneráló hatására kevés az empirikus bizonyíték. Ashrafés szerzőtársai [2016] sem talált bizonyítékot az FDI termelékenységnövelő (TFP) hatására.

A külföldi működőtőke-befektetések fogadó országra gyakorolt hatását többen elemezték. A külföldi tulajdonban levő vállalatok pozitív hatása jelentős lehet a fogadó gazdaság teljesítményére (Blomström-Kokko [1997]), különösen az átalakuló gazdaságokéra. Többek között Lankes-Venables [1996] szerint a külföldi működőtőkebefektetések potenciális katalizátorai az átalakulási folyamatnak. Felgyorsíthatják a gazdaság fejlődését és a tervgazdaságból a piacgazdaságba történő átmenetet. Megnövelhetik a tőkében és új beruházásokban szegény fogadó gazdaság termelési kapacitásait. A müködőtőke-befektetés emelheti a termelékenység szintjét és a versenyképességet. Technológiát és know-how-t hozhat a fogadó gazdaságba, menedzseri és marketingismereteket és technikákat adhat át a helyi cégeknek az interakciók révén. Segítheti a piacok, a gazdasági szereplők piaci viselkedésének, kultúrájának és a piaci intézményeknek a fejlődését.

Ezek a pozitív hatások azonban nem automatikusak. A külföldi tulajdonban levő vállalatok működhetnek elkülönült „szigetként” is a fogadó gazdaságban, ahol nagyon kevés kapcsolatuk lehet a befogadó gazdaság szereplöivel. A fogadó ország viszonylag alacsony technológiai szintjét „konzerválhatják” azzal, ha alacsony hozzáadott értékü tevékenységeket végeznek. A fogadó gazdaság túlzott specializációját 
okozhatják, amennyiben csak néhány terméket gyártanak helyben, és így növelhetik a világgazdasági folyamatok és az üzleti ciklusok szempontjából ezen gazdaságok sebezhetőségét. A kormányzati gazdaságpolitika ennek megfelelően megpróbálja a mérleget a pozitív hatások felé billenteni.

A fogadó gazdaságra gyakorolt hatásokat vizsgáló empirikus tanulmányok nem jutottak egyértelmü eredményre. Sok esetben az empirikus elemzések nem tudtak pozitív és/vagy szignifikáns kapcsolatot kimutatni a külföldi müködőtőkebefektetések és a gazdasági növekedés között. Példaként említve, a több országot elemző cikkek sem találtak pozitív hatást (De Mello [1999], Carkovic-Levin [2002] vagy Lipsey [2000]). Mások szerint a pozitív hatás csak bizonyos tényezők esetén érvényesül (például Alfaro és szerzötársai [2004] azt mutatta ki, hogy a jól működő pénzügyi szektorral rendelkező országok „profitálnak” a müködőtőkebeáramlásból). Hermes-Lensink [2003] szerint az FDI pozitív hatása függ az adott ország abszorpciós kapacitásától, és ez a pozitív hatás leginkább csak a fejlett gazdaságokban érvényesül. De Mello [1999] is kimutatta, hogy az FDI pozitív hatása csak az OECD-országokban érvényesül, míg az OECD-n kívül negatív a hatás. Borensztein és szerzőtársai [1998] eredményei szerint az FDI növekedést generál a technológiatranszfer révén, de ez a hatás lehet pozitív, az emberi tőke szintjétől és a fogadó gazdaság abszorpciós kapacitásától függően. Chowdhury-Mavrotas [2006] szerint szintén a fogadó gazdaság emberitőke-állományától függ a pozitív hatás érvényesülése. Greenaway-Görg [2001] 30 empirikus tanulmány eredményeit összegezve arra jutott, hogy a pozitív és a negatív hatások egyaránt jelen vannak a fogadó gazdaságban, és kiolthatják egymást. Campos-Kinoshita [2002] vagy Neuhaus [2006] szerint az átmeneti gazdaságok esetében az FDI pozitívan és szignifikánsan hatott a gazdasági növekedésre. Iwasaki-Tokunaga [2014] metaanalízis alapján összegezte az átalakuló országokban a külföldi müködőtőke-befektetések makrogazdasági hatásait vizsgáló tanulmányok eredményeit, és azt találta, hogy a számítások jellemzői (vizsgált időszak, adattípus, becslési módszer, a müküdőtőke-befektetés típusa) jelentősen befolyásolták az eredményeket. Így további kutatás szükséges a kapcsolat nagyságának és erősségének meghatározására.

A főáramú szakirodalom is elismeri, hogy az FDI egyértelmü pozitív növekedési, termelékenységnövelő és technológiai hatása csak a fogadó ország megfelelő abszorpciós képessége esetén érvényesül, s ezek a feltételek leginkább csak a fejlett országokban vannak meg (Bermejo Carbonell-Werner [2018]). Az FDI és a gazdaság fejlettsége közötti ok-okozati kapcsolat iránya tehát nem triviális: a külföldi működőtőke beáramlása rövid (beruházások serkentése, átgyürüző hatás, keynesi multiplikátor) és hosszú távon (technológiai transzfer, menedzsmenttudás, know-how) is elősegítheti a gazdaság fejlődését. A kapcsolat irányát azonban megfordítva, a fejlettebb gazdaság éppen a kedvezőbb intézményi feltételeinek, kisebb kockázatának köszönhetően vonzhat több külföldi müködőtőkét magához, illetve a külföldi befektetések jobban hasznosulhatnak a fejlettebb pénzügyi piacokon (Alfaro és szerzötársai [2004], Bermejo Carbonell-Werner [2018]).

Narula-Guimón [2010] az FDI-vezérelt fejlődés legsikeresebb példáit azon országok (Îrország, Costa Rica és a kelet-ázsiai újonnan iparosodó országok) esetében 
azonosította, ahol a (fejlesztő) állam egyszerre folytatott sikeres FDI-vonzó és a hazai vállalatok versenyképességét is növelö gazdaságpolitikát (Bailey és szerzötársai [2016]). Te Velde [2001]), és Rugraff [2010] megállapította, hogy az aktív, a hazai vállalkozásokat támogató gazdaságpolitika hiányában a kelet-közép-európai régióban befektető multinacionális vállalatok a pozitív interakciók és átgyürüző hatások hiányában nem segítették (kiszorító hatásukkal akadályozták) a hazai multinacionális vállalattá válást. Bermejo Carbonell-Werner [2018] spanyolországi vizsgálatai az 1984 és 2010 közötti időszakban egy relatíve fejlett pénzügyi piacon is az FDI negatív hatását mutatta ki a gazdasági növekedésre. Ugyanakkor a hazai tulajdonú bankok által teremtett hitel a reálszektorban pozitív hatást gyakorolt a gazdasági növekedésre.

Prasad és szerzőtársai [2008] negyven fejlődő ország adatait elemezve arra a következtetésre jutott, hogy a külső tőkeforrásokra támaszkodó fejlődő országok lassabban növekednek, mint a saját megtakarításokra támaszkodók. Azon országok növekedése gyorsabb, amelyek beruházási rátája nagyobb, és kevésbé támaszkodnak a külföldi tőkére. Tehát a külföldi tőke negatívan hat a növekedésre a kevésbé fejlett piacokon! A szerzők azt is kimutatták, hogy azokban az országokban, amelyekben magasabb a beruházási ráta, illetve a külföldi tőkétől való függés kisebb (azaz alacsony a folyó fizetési mérleg hiánya tehát nagyobb a többlet), gyorsabb a gazdasági növekedés, mint a külföldi tőkével beruházó országok esetében. Megállapították, hogy a fejlődő országok nagyobb mértékben támaszkodtak a külföldi tőkeforrásokra. Arra jutottak, hogy a közép- és kelet-európai országok e tekintetben inkább a fejlett országokra hasonlítanak, ahol a külfölditőke-import (a fizetésimérleg-hiány ellenére) pozitív hatást gyakorolhat a növekedésre.

A hazai szakirodalomban Balatoni-Pitz [2012] számszerüsítette az FDI bruttó nemzeti jövedelemre (GNI) gyakorolt hatását, és összevetette azt az alternatív külső finanszírozási formákkal. A külföldi befektetők motiváltak a kevésbé fejlett országokban való beruházásra a magasabb határtermelékenységből következő magasabb kamatok miatt. Ugyanakkor rövid idősoros elemzésükben a tőkekivonás hatásait a szerzők nem vizsgálták. Bélyácz-Kuti [2009] a külföldi müködőtőke és a külső eladósodás összefüggéseit elemezve megállapította, hogy a külső források sohasem lesznek képesek ellensúlyozni az alacsony fokú belső megtakarítás, a csupán enyhén pozitív külkereskedelmi mérleg, az államháztartási túlköltekezés, a reálgazdaságon kívüli fogyasztás, valamint a hitelből finanszírozott tőkeexport negatív hatását.

Az FDI regionális hatásait elemző munkák kiemelik az FDI termelékenységnövelö hatását, ami a gazdasági növekedés motorjává vált a spanyol régiókban (Bajo-Rubio és szerzőtársai [2010]). Casi-Resmini [2017] szerint az olasz régiókban az FDI átgyürüző hatásai a növekedés meghatározó tényezői lehetnek, de csak abban az esetben, ha az intézményi és az üzleti környezet abszorpciós képessége megfelelö. Az átgyürüző hatás azonban gyengébb a feldolgozóiparban, mint a szolgáltatásokban. Pavlinek [2004] Csehország példáján elemzi a külföldi müködőtőkének a duális gazdasági szerkezet kialakulására és az egyenlőtlen területi fejlődésre gyakorolt hatásait. Kiemeli, hogy a külföldi nagyvállalatok átgyürüző hatásai regionális szinten is korlátozottak a beszállítói láncot és a K + F-et tekintve. Skersan-Skabic-Tijanic [2014] szerint a horvát régiók esetében az FDI pozitívan befolyásolta a regionális fejlödést, ugyanakkor 
ez függ a régiók abszorpciós képességétől. Antalóczy-Sass [2005] Magyarországra vonatkozóan dokumentálta a külföldi érdekeltségű vállalatok erős területi koncentrálódását, és azt is megmutatta, hogy nemcsak az egy före jutó GDP területi eloszlása hasonlít az egy före jutó külföldi tőke elosztására, hanem a beruházásoké, az exportértékesítéseké, az átlagkereseteké és a foglalkoztatási rátáé is. A külföldi müködötőkével ellátottabb megyék ezeken a területeken jobban teljesítenek. Hasonló megállapításra jutott Lengyel-Varga [2018] a magyar gazdasági növekedés tényezőit vizsgálva megyei szinten. Magyarországon nem a fejlett üzleti szolgáltatásokat, a K+F-et és a képzett munkaerőt koncentráló főváros, hanem a feldolgozóipari FDI-t koncentráló öt megye élénkíti a gazdaságot és húzza az ország GDP-növekedését.

\section{Az FDI szerepe a kelet-közép-európai gazdaságokban}

A külföldi tőkebefektetések alapvetően segítették a posztszocialista országokat a régió (külföldibefektetés-vezérelt) fejlödési pályáinak alakításában. A térség relatív gazdasági fejlettsége és a nyugat-európai befektetőkhöz való közelsége miatt vonzóvá vált a külföldi működőtőke-befektetők számára. Egyrészt a nemzetközi tőke piaci lehetőségeket keresett Kelet-Európában, ami egybeesett az állami tulajdonú vállalatok tömeges privatizációjával és a térség európai integrációjának megindulásával (Schmidt [2014]). Ez utóbbi tovább növelte a régió FDI-vonzerejét (Gál-Schmidt [2017]).

A külföldi müködőtőke a feldolgozóipari privatizáció, illetve a fejlett üzletipénzügyi szolgáltató szektor külföldi tőkebefektetéseinek meghatározó típusává vált (Kalotay [2010]). A külföldi müködőtőkétől a tőkehiányos kelet-közép-európai régióban új tőkeforrások folyamatos biztosítását, az új technológiák és vállalatirányítási rendszerek meghonosítását, munkahelyteremtést és a gazdasági növekedés felfutását, végső soron a tágabb régió gyors felzárkózását várták. Az államszocializmusról a piaci kapitalizmusra való áttérést követően (1990-es évek), az átmenet második szakaszában gyorsan következett be az ipari kapitalizmusból a pénzügyi kapitalizmusba való átmenet. Az ezredforduló után a külföldi banktőke vált a legfontosabb tőkebefektetési formává, a fenntarthatatlan financializált és fogyasztásvezérelt növekedés motorjává (Gál [2013]).

A külföldi működőtőke beáramlása drámai változásokat eredményezett a tulajdonosi struktúrákban, először a banki és biztosítási szektorban, majd a feldolgozóiparban. Az FDI részesedése a GDP-n belül a legmagasabb Magyarországon (67 százalék) és Csehországban (72 százalék), ami nemcsak e gazdaságok integrációját jelzi az EU gazdaságában, de a külföldi multinacionális vállalati értékláncoktól való függőséget is. Szlovákiában (54 százalék) és Lengyelországban (25 százalék) alacsonyabb volt az FDI részesedése, ami összehasonlítható az osztrák értékkel (23 százalék) (Lux [2017]). A külföldi leányvállalatok részesedése a feldolgozóipari termelésben a legmagasabb Szlovákiában (80 százalék) és Magyarországon (70 százalék).

A régió külső tőkétől való függősége nemcsak a nyugat-európai feldolgozóipartól való exportfüggőséget, hanem technológiafüggőséget is generált (Raviv [2008]). Mindez lehetetlenné tette az autonóm, belső erőforrásokra támaszkodó, 
innovációvezérelt növekedést és felzárkózást. Ehelyett a függő helyzetben lévő keleteurópai piacgazdaságokban a külföldi tőkebefektetéseken alapuló, beruházásvezérelt (illetve külkereskedelem-vezérelt) növekedési modell vált jellemzővé a belső megtakarításon, a hazai vállalati beruházásokon és a belföldi fogyasztáson alapuló növekedés helyett (Nölke-Vliegenhart [2009], Gál-Schmidt [2017], Schmidt [2015]).

A mainstream elméletek szerint a külföldi vállalatok pozitívan befolyásolhatják a fogadó ország gazdasági teljesítményét (Blomström-Kokko [1997]). A külföldi működőtőkére egyoldalúan úgy tekintettek, mint a piacgazdasági átmenet, a gazdasági növekedés és a beruházások potenciális katalizátorára, ami növeli a termelékenységet és a versenyképességet a technológia és a menedzseri tudás átadása révén (Grossman-Helpman [1991]). Ezek a pozitív hatások azonban nem jelentkeztek automatikusan, ehelyett „duális gazdasági szerkezet” alakult ki az átmeneti gazdaságokban, amelyet a külföldi és a hazai vállalatok közötti mély szakadék jellemez az export, a termelékenység, a versenyképesség, a technológiai tudás (innováció) és a piaci pozíció tekintetében (Hardy [1998], Barta [2005]). Lux [2017] felhívja a figyelmet, hogy az FDI-vezérelt modellt egyrészt jelentős vállalatok közötti és térbeli különbségek jellemzik, másrészt jelentős - a negatív mellékhatásokat figyelembe véve - a növekedési pálya hosszú távú fenntarthatóságának bizonytalansága.

Mileva [2008] pozitív és szignifikáns kapcsolatot mutatott ki a külföldi működőtőke és beruházások között az átmeneti gazdaságokban. Statisztikai adataink alapján látható, hogy a magasabb beruházási rátával rendelkező országokban az egy főre jutó GDP növekedése nagyobb, mint az alacsonyabb beruházási rátájú országok esetében. Az 1. ábrán látható, hogy az állótőke-beruházások és a GDP növekedése között lineáris a kapcsolat, és erős az együttmozgás.

\section{1. ábra}

A bruttó állótőke-felhalmozás növekedése (bal tengely, százalékpont) és a GDP növekedési rátája (jobb tengely, százalék) közötti kapcsolat a visegrádi országokban

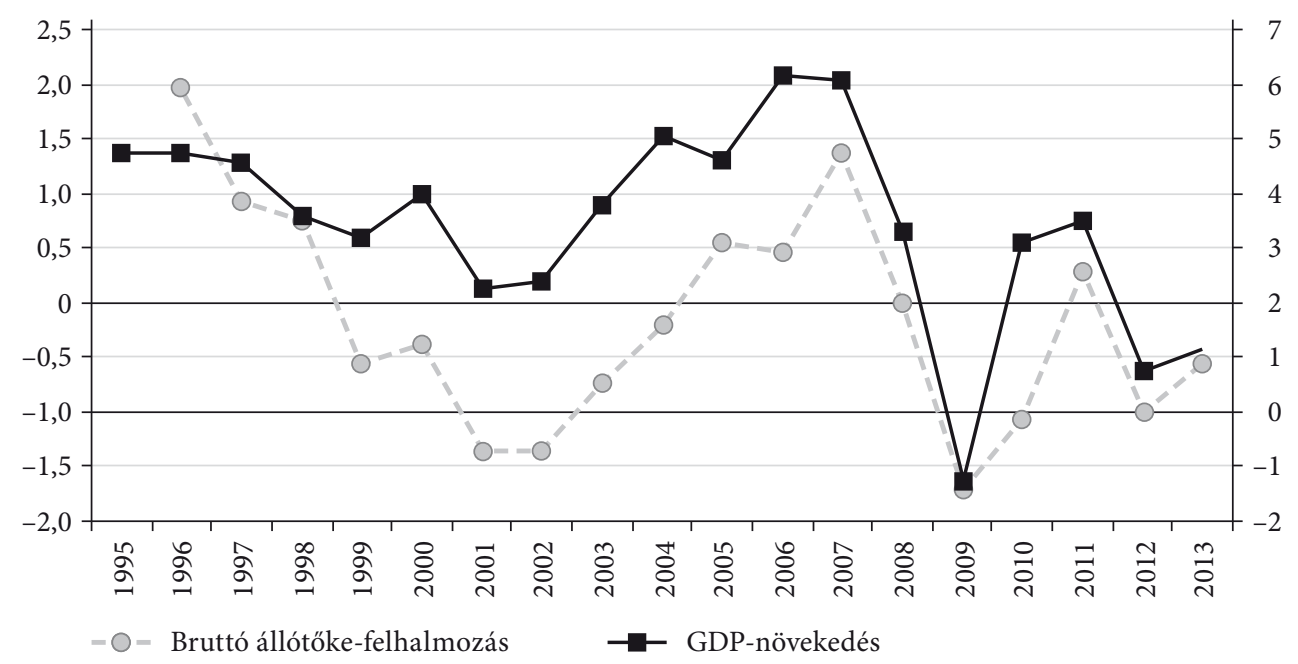

Forrás: saját szerkesztés a Worldbank adatai alapján. 
Statisztikai adatbázisunkon teszteltük, hogyan hat az FDI a bruttó állóeszköz-felhalmozásra a visegrádi országokban. A 2. ábrán látszik, hogy nem mutatható ki egyértelmủ kapcsolat az FDI és az állóeszköz-beruházások között. Balatoni-Pitz [2010] is csökkenő beruházási rátát mutatott ki Magyarországra vonatkozóan 1995 és 2010 között, s ezen belül az FDI súlya még erősebben csökkent (1997: 32 százalék, 2010: 8,5 százalék). A visegrádi négyek esetében az FDI részaránya a beruházásokon belül 2006 és 2013 között 25 százalékról 7 százalékra esett vissza, ami részben magyarázza is a két változó széttartását.

\section{2. ábra}

Kapcsolat a bruttó állóeszközök felhalmozása a GDP százalékában (jobb tengely) és az FDI-állomány a GDP százalékában (bal tengely) között a visegrádi országokban

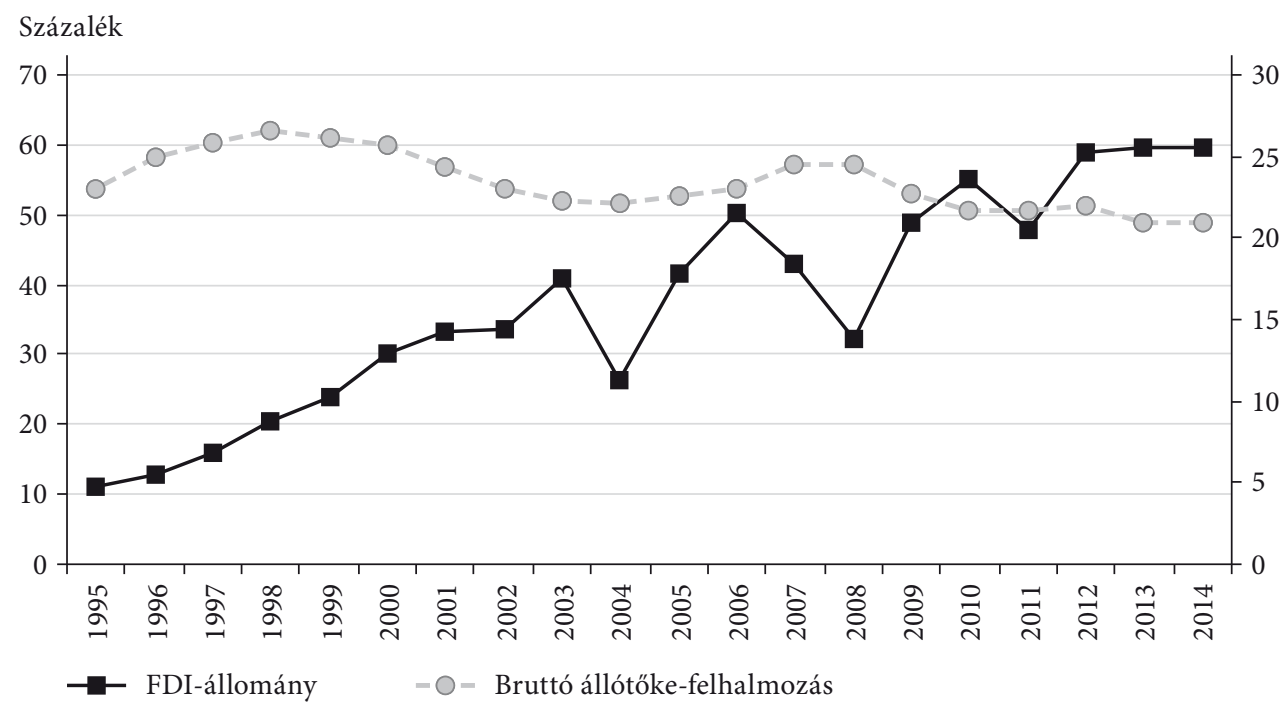

Forrás: saját szerkesztés Worldbank és az UNCTAD adatai alapján.

Ugyanakkor a Magyarországnál fejlettebb országokban (például Spanyolországban) a hosszú lejáratú, hazai bankok által nyújtott bankhitelek generálják leginkább a hazai beruházásokat (Bermejo Carbonell-Werner [2018]), míg az FDI esetében hosszú távon csak kismértékü - beruházásokra gyakorolt - túlcsorduló hatás mutatható ki. Dombi [2013] a tőkeállomány bővülését, míg Kónya [2015] a TFP-bővülés szerepét hangsúlyozta a növekedésben. Mások szerint azonban a külföldi müködőtőkét befogadó átmeneti gazdaságok inkább hasonlítanak e tekintetben a fejlödő országokhoz, mint a fejlettekhez, következésképpen az FDI negatívan hat a növekedésre (Jensen [2006]).

A következőkben a külföldi működőtőkének a befogadó gazdaságra gyakorolt negatív hatásait foglaljuk össze röviden. A duális gazdaságokban a külföldi nagyvállalatok és a hazai tulajdontöbbségű vállalatok tartós, elszigetelt egymás mellett élése jellemző, mivel jelentős beszállítói hálózatok nem jöttek létre, így az átgyủrüző hatások szerepe is csekély. Ezen túlmenően a külföldi nagyvállalatok egyenlőtlen versenye kiszoríthatja a hazai cégeket a stratégiai szektorokból (autóipar, elektronika, bank és 
biztosítás), mivel a multinacionális vállalatok a hazai cégek termék- és munkaerőpiacait foglalják el (Lux [2017]).

A gazdaság versenyképessége nem a radikális és a járulékos innovációkon nyugszik, hanem a külföldi üzemek közepes technológiaszintet igénylö, standardizált összeszerelő platformjain (Lux [2017b]). A közvetlen külföldi tőkebefektetések jövedelmi hatásai nagyon korlátozottak, mivel az e projektekből származó bevételeknek csak kis hányadát tudják a fogadó országok „megcsapolni” (Lane-Milesi-Feretti [2007]). Az átmeneti gazdaságokban a GDP és a GNI közötti növekvő rés elkerülhetetlen következménye az FDI-beáramlásnak, ahol a különbség idővel növekszik. Ez a különbség a kelet-közép-európai országokban átlagosan a GDP 0,96 százalékáról 4,38 százalékra nőtt. Ha a GNI elmarad a GDP-től, akkor kevesebb jövedelemből gazdálkodhat egy ország, mint amennyi az adott ország területén létrejött. Ez annak köszönhető, hogy a külföldi befektetésekből származó jövedelmek növekvő részét visszavezetik a tőke tulajdonosainak anyaországába.

Az FDI-beáramlásnak közvetlen, egyszeri pozitív hatása van a fizetési mérlegre, mivel az FDI jelentős szerepet játszik a folyó fizetési mérleg magas hiányának a finanszírozásában (a fejletlen tőkepiacból fakadó belső tőkehiányt kompenzálja; igaz, hogy implicit kamata más tőkeforrásokkal összehasonítva a legmagasabb, mivel az FDI hosszabb lejáratú és kevésbé likvid befektetés; Balatoni-Pitz [2012]). Balatoni-Pitz [2012] szerint a többi finanszírozási formának jóval kisebb a növekedési hatása. Ezt cáfolja Bermejo Carbonell-Werner [2018] spanyolországi empirikus elemzése, ami az FDI negatív hatását mutatta ki a gazdasági növekedésre, míg a hazai bankok által teremtett hitel a reálszektorban pozitív hatást gyakorolt rá.

Hosszabb távon azonban az FDI a folyó fizetési mérleg hiányát növeli, mivel a közvetlen külföldi tőkebefektetések profitjövedelmeit egyre inkább kivonják a fogadó gazdaságból. Ez azzal a ténnyel függ össze, hogy az FDI egyes részei (saját tőke, újra befektetett tőke, osztalék, egyéb tőke) mobilak. A másik ok, hogy a külföldi beruházások importhányada rendkívül magas, illetve az export hazai hozzáadott értéke rendkívül alacsony (Gál-Schmidt [2017]). Ez egyúttal azt is jelenti, hogy külkereskedelmi hiányt termelnek, jelentősen rontják a célországok, így Magyarország külkereskedelmi mérlegét (Balatoni-Pitz [2012]).

Ha a külföldi vállalat beruházása finanszírozásához a célországból is bevon forrásokat, akkor kiszoríthatja a hazai beruházásokat, hiszen leköti a hazai megtakarítások egy részét. Ráadásul ha sok profitot visz ki az országból, akkor egyáltalán nem lehet arra számítani, hogy javítaná a célország tőkeellátottságát. Az adóbevételek növekedése túl kis mértékủ lehet, ha a kormányzat adókedvezményekkel próbálja az országba csalogatni a külföldi tőkét, valamint ha a leányvállalat és az anyavállalat úgy állapítja meg az egymás közti transzferárakat, hogy a kedvezőbb adózási feltételeket biztosító országban keletkezzen az adókötelezettség nagy része.

Ha a külföldi tulajdoni többségü vállalatok nem ágyazódnak be a hazai gazdaságba, és/vagy kiszorítják a versenyből a hazai cégeket, akkor nem lehet arra számítani, hogy megvalósuljon a technológiatranszfer és a korszerü menedzsmentismeretek átadása. Ezeken kívül néhány további hátrányt is felsorol Todaro-Smith [2012]. A külföldi müködőtőke-beruházások hozzájárulhatnak a duális gazdasági szerkezet 
kialakulásához, valamint a regionális és jövedelmi egyenlőtlenségek növekedéséhez. Sokan azt tartják a külföldi müködőtőke egyik legfőbb előnyének, hogy munkahelyeket teremt, azonban a külföldi anyacégek gyakran tőkeintenzív termelést szerveznek ki ezekbe a leányvállalataikba, és az összeszerelő tevékenység nem igényel sok és magasan képzett munkaerőt. További negatívumként említik, hogy az erős külföldi vállalatok gyakran saját érdekükben képesek befolyásolni a hazai politikai döntéseket, valamint kiszoríthatják a hazai vállalatokat a versenyböl.

Számos tény bizonyítja, hogy a külföldi müködőtőke-beáramlás duális gazdasági szerkezetet hozott létre. ${ }^{1}$ A térben egyenlőtlen megoszlás egyik jellemzője a szigetszerü müködés, ami a külföldi vállalatok alacsony beágyazottságát is jelzi a magyar gazdaságba. Jelentős beszállítói hálózatok hiányában a legfőbb kapcsolódási pontjuk csupán annyi, hogy helyi munkaerőt (is) foglalkoztatnak. A szigetszerüség megnyilvánulási formái: 1 . a nyersanyagokat föként importból szerzik be, a termékeiket pedig exportpiacokon értékesítik, csak csekély mértékben támaszkodnak hazai beszállítókra; 2. a profit nagy részét nem a hazai gazdaságban fektetik be újra, hanem kiviszik az országból; 3. a kutatás-fejlesztésben minimális az együttmúködés a külföldi és a hazai tulajdoni többségben lévő vállalatok között.

\section{A külföldi müködőtőke hatása a gazdasági növekedésre a magyarországi megyékben és területi megoszlása Magyarországon}

A gazdasági növekedés tényezőinek egyenlőtlen térbeli eloszlása szubnacionális szinten is szembetünő. Lengyel-Varga [2018] vizsgálta az általuk tipizált öt magyarországi megyetípus (Centrum, FDI feldolgozóipari, Újraiparosodó, TudÁsKözpont, RuRÁLIS) hozzájárulását a GDP növekedéséhez. A tanulmány fontos megállapítása, hogy a válság időszakától eltekintve a legstabilabb növekedést az FDI-vezérelt feldolgozóipari megyék produkálták, s 2013 után elöretörésük még szembetünőbb e tekintetben. A kevésbé fejlett újraiparososdó megyék is dinamikusan növekedtek, esetükben is a külföldi müködőtőke az egyik meghatározó növekedési tényezö lehet.

A közel két évtizedig következetesen követett FDI-vezérelt növekedési politika eredményeként a korán erre a pályára állt megyék bizonyultak hosszabb távon a leginkább „sikeresnek” (bár belső ellenálló képességük gyengébb és erősen függ a külső hatásoktól), különösen a globális válságot követő pénzbőség és a globális befektetési boom időszakában. Ennek a növekedési pályának a hátterét a 2010-es évek közepéig folyamatosan növekvő, olcsó és a térségben mozgó munkaerő adta. A kedvező

${ }^{1}$ Kádár-Markovszky [2002] kifejti, hogy 2000-ben az összes magyarországi vállalat 9 százaléka volt külföldi többségủ tulajdonban, ehhez képest ők adták a magyar gazdaság összes beruházásainak 57 százalékát, a bruttó hozzáadott értékének 50 százalékát és exportjának 75 százalékát. Mindeközben a hazai többségi tulajdonban lévő cégek többnyire kis- vagy közepes vállalkozások, amelyek hazai piacra termelnek, és a kiskereskedelemre, az idegenforgalomra, személyi szolgáltatásokra specializálódnak, amely területeken nincs is mód jelentősebb exportra. A leginkább exportképes, feldolgozóipari ágazatban az összes árbevétel 72 százalékát külföldi többségű tulajdonban lévő vállalatok tudták magukénak 2005-ben (Barta és szerzötársai [2007]). 
változások fenntartásában jelentős szerepet játszott a kormányzati gazdaságpolitika, amely jelentős forrásokat juttatott az itt befektető külföldi cégeknek. ${ }^{2}$

A rendszerváltást követően Magyarországon közel két évtizedig a külföldi tőkebefektetések a gazdasági megújulás egyik legfontosabb eszközét jelentették: nem hiteljellegü tőkeforrást biztosítottak a beruházásokhoz, hanem a technikai megújulás fontos csatornájával, a technológiatranszferrel, valamint - beszállítói hálózataik révén - erösebb gazdasági beágyazódással kecsegtettek. A globális gazdaság értékláncaiba való integrálódás olcsó munkaerőre, közepes technológiára és összeszerelő platformokra épül. Ebben az FDI-(befektetés)vezérelt (növekedési) stratégia vezető szerepet játszott. Az exporton belül a magas feldolgozottságú termékek kiugró aránya nem fedheti el a tényt, hogy az országba települt külföldi termelőcégek a nemzetközi értékláncokban az alárendelt pozíciójú, egymással erős árversenyben lévő lokális beszállítói pozíciókban (Tier3, Tier4) foglalnak helyet. Az ország külső függősége magas, a külföldi működőtőkével működő leányvállalatok részesedése a bruttó hozzáadott értékből kiemelkedő (57 százalék) Magyarországon, míg az EU-átlag 24 százalék. A feldolgozóiparban a termelési érték 70 százalékát adták 2015-ben, az export közel felét szintén e cégcsoportok adják (Gál-Schmidt [2017]), miközben az exporton belül a hazai hozzáadott érték 55 százalékos aránya (Szlovákiával együtt) az EU-ban az egyik legalacsonyabb. A külpiaci aktivitás egyrészt magas importhányaddal párosul, másrészt túlnyomó részben vállalatcsoporton belüli árumozgást jelent, vagyis az árukat a cégcsoporton belüli transzferármechanizmusok mozgatják. A multinacionális cégek foglalkoztatásgeneráló szerepe mérsékelt, hálózataikon keresztül a munkaerő alig ötödét foglalkoztathatják (a vállalkozások 4 százaléka külföldi). E vállalatok beágyazottsága a lokális gazdaságba szerény, a húzóágazattá fejlődött autóipar esetében a „hazai” beszállítók többsége külföldi tulajdonú cégek magyarországi leányvállalata.

A külföldi beruházások nemcsak a gazdaság modernizációjához járultak hozzá, de a „duálissá” váló gazdaság strukturális és térbeli differenciáit is jelentősen növelték (Gál-Juhász [2016] 6. o.). A magyar megyék egy före jutó GDP-jének kvartilistérképén jól látszik a strukturális és térbeli különbségek alakulása (3. ábra). A sötétebb szín jelzi a magasabb kvartilisbe tartozó megyéket. A 4. ábrán hasonló kvartilistérképek mutatják a megyék egy főre jutó külföldi tőkeállományát. A két ábra jelentős átfedést mutat: mindkettő szerint az ország legfejlettebb megyéi Közép-Magyarországon, Nyugat-Dunántúlon és Közép-Dunántúlon találhatók, és az egy före jutó külföldi tőkeállomány is ezekben a régiókban a legnagyobb. Ugyanakkor a fejletlenebb kelet-magyarországi és dél-dunántúli térségekben a külföldi működőtőke is kevesebb. A Centrumban koncentrálódik a legtöbb külföldi müködötőke, ami az országos hatókörű külföldi nagyvállalati székhelyek (pédául elsősorban szolgáltatócégek) itteni koncentrációjának a következménye. A Centrum 2015-ig folyamatos növekedést mutatott. Az FDI FELDOLGOzóIPARI térségek az egy före jutó külföldi müködőtőke tekintetében pedig 2010-töl mutatnak folyamatos növekedést (Lengyel-Varga [2018]).

\footnotetext{
${ }^{2}$ Az egyedi kormányzati támogatások jelentős mértékben járultak hozzá új cégek letelepedéséhez vagy a már itt termelők/szolgáltatók életciklusának meghosszabbításához, illetve munkahelyteremtésének finanszírozásához, s 2004 óta nagyjából 300 milliárd forintos nagyságrendet értek el.
} 
3. ábra

A magyar megyék egy före jutó GDP-jének kvartilistérképe, 2014 (ezer forint/fö)

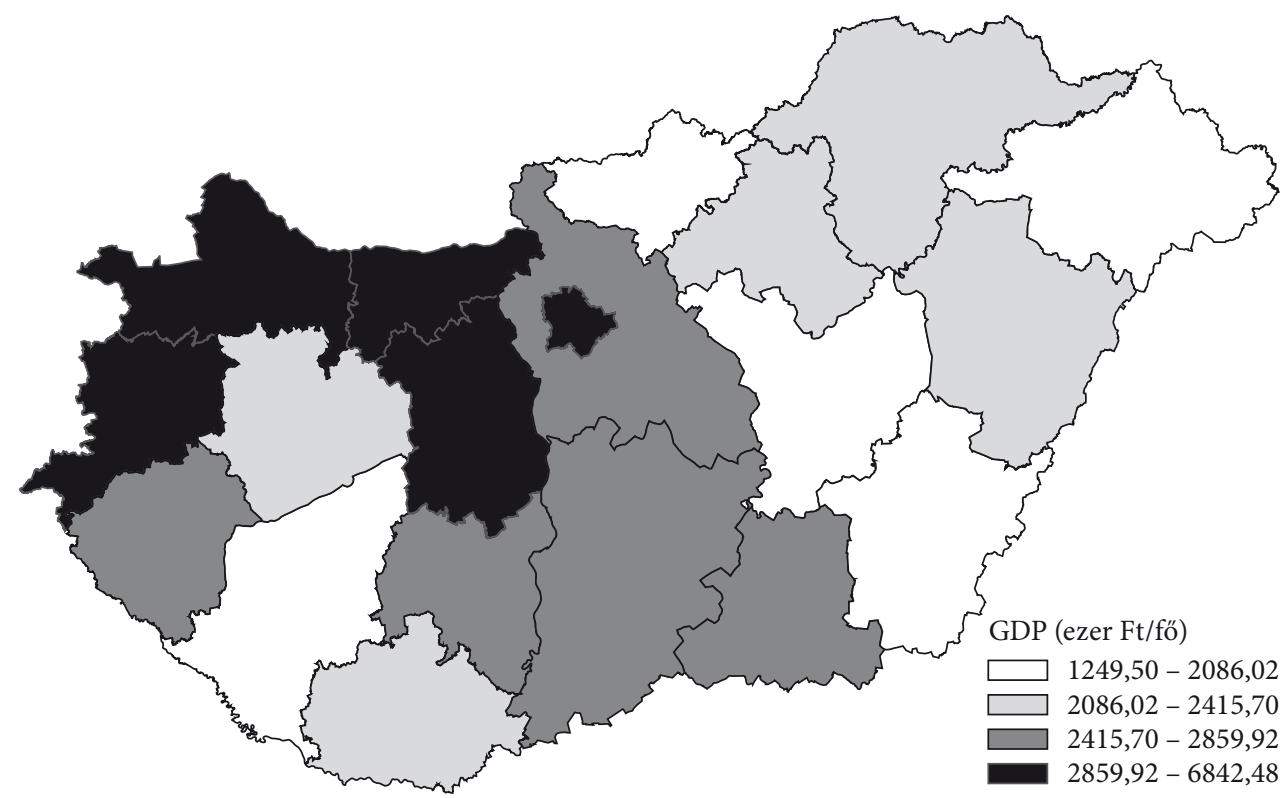

Forrás: a KSH adatai alapján saját szerkesztés.

\section{4. ábra}

A külföldi mủködőtőke-befektetéssel müködő vállalatok egy före jutó külföldi jegyzett tőkéjének eloszlása a magyar megyék között, 2014 (millió forint/fö)

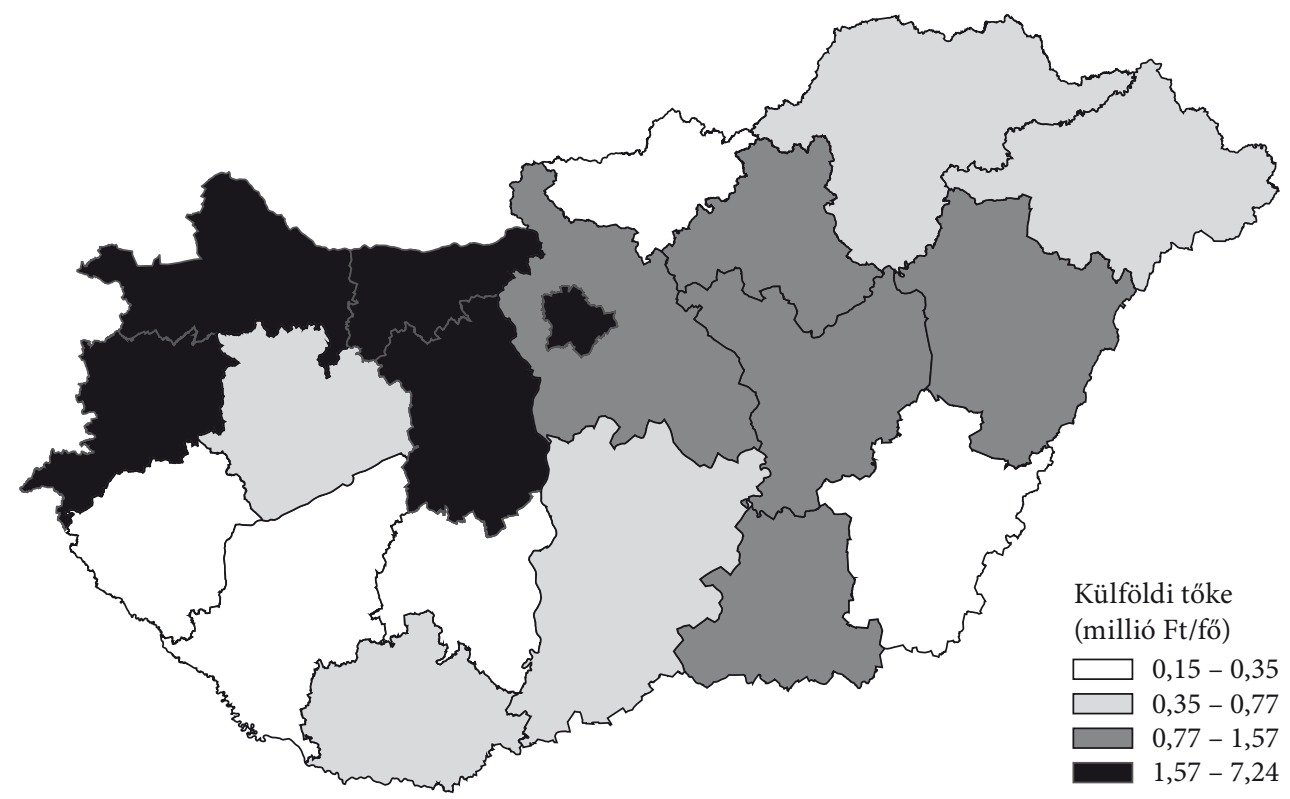

Forrás: a KSH adatai alapján saját szerkesztés. 
Nem új keletű jelenségről van szó: Antalóczy-Sass [2005] mintegy 15 évvel ezelőtt dokumentálta, hogy 2002-ben a külföldi érdekeltségủ vállalatok 60 százaléka KözépMagyarországon koncentrálódott, Közép- és Nyugat-Dunántúllal együtt pedig ez a három régió összpontosította a külföldi érdekeltségü vállalatok 77 százalékát. A területi részesedések a rendszerváltás óta stabilnak mondhatók, sőt inkább mutatnak a további koncentráció, mint a kiegyenlítődés irányába. A külföldi tőkét koncentráló három régió 1994-ben az ország GDP-jének 60,8 százalékát adta, 2002-ben viszont már a 64 százalékát. A szerzőpáros azt is kimutatta, hogy nemcsak az egy főre jutó GDP területi eloszlása hasonlít az egy főre jutó külföldi tőkééhez, hanem a beruházásoké, az exportértékesitéseké, az átlagkereseteké és a foglalkoztatási rátáé is.

Lengyel-Varga [2018] egyik fö következtetése, hogy Budapest és vonzáskörzete generálta elsősorban a gazdasági növekedést 2007-ig, 2010-től azonban már egyértelmüen visszafogta növekedés ütemét. Több lehetséges magyarázat közül fontos tényező a fóváros alacsony tőkevonzása, ami az EU-források esetében természetesnek mondható, mivel nem konvergenciarégió, ám a kormányzati beruházások és a külföldi források bevonásában mutatott gyenge teljesítmény, valamint az európai nagyvárosi hálózatokhoz való alacsony intenzitású kapcsolódás is jelzi Budapest pozícióvesztését. A fejlett pénzügyi és üzleti szolgáltatások magasabb hierarchiájú intézményeinek vonzásában a szálláshelyszolgáltatás, vendéglátás (I) és a pénzügyi, biztosítási tevékenység (K) szektorbeli FDI is jelentős pozíciókat vesztett Budapest régiós versenytársaihoz képest.

A külföldi működőtőkével ellátottabb megyék jobban teljesítenek. Némileg árnyalja a polarizált képet, hogy az egy külföldi vállalatra jutó saját tőkét és árbevételt tekintve Nyugat-Dunántúl áll az első helyen, sőt még Közép-Dunántúl is megelözi Közép-Magyarországot. Tehát igaz az, hogy bár a külföldi müködőtőke nagy része Budapesten és környékén összpontosul, de külföldi vállalatok az ország északnyugati részén intenzívebben fektetnek be a járműiparba és a feldolgozóiparba. 2000 és 2011 között ugyan 61-ről 71 százalékra nőtt Közép-Magyarország részesedése a külföldi érdekeltségű vállalatok számából (ami 2016-ra 65 százalékra visszaesett), de a külföldi tőkéből a CENTRUM régió részesedése 67-ről 59 százalékra csökkent. Ez elsősorban annak köszönhető, hogy Nyugat-Dunántúlon tőkeintenzív külföldi vállalatok jelentek meg, így a régió 11-ről 21 százalékra tudta növelni a külföldi vállalatokból való részesedését. ${ }^{3} A$ válság elött az ipari működőtőke három térségben tömörült, egyenként 18-24 százalékos aránnyal: Budapest, Közép- és Nyugat-Dunántúl, de Pest megye és Észak-Magyarország is jelentős, 9-12 százalékos arányban részesedett az ágazatba fektetett tókéből (Lux [2017a]).

A 2008-as válság előtt a külföldi müködőtőke negyede koncentrálódott a feldolgozóiparban, 40 százalékát pedig fejlett üzleti, pénzügyi és informatikai szolgáltató tevékenységekben. 2016-ra az FDI ágazati szerkezete látványosan átrendeződött: több mint 40 százalékra nőtt a feldolgozóiparbeli aránya (ezen belül az autógyártás súlya önmagában 43 százalék), s bár az üzleti szolgáltatások is bőven átlépték az 1000 milliárdos küszöböt,

${ }^{3}$ A cégek további 9-10 százaléka működik Pest megyében, míg vidéken az egyedüli kiemelkedő térségként Győr-Moson-Sopront azonosíthatjuk (4-5 százalék). Vidéken Győr-Moson-Sopron (12-13 százalék) mellett Fejér megye jelentősége is kiemelhető (5,5 százalék), de 300 milliárd forint feletti tőkeállomány további nyolc megyében - köztük kelet-magyarországiakban is - működik. 
együttes arányuk mégis 37 százalékra csökkent. A feldolgozóipar súlyának növekedése a teljes FDI-állományban felértékelte a jelentős ipari működőtőkét vonzó régiókat. Az ipari FDI térszerkezete 2016-ra átalakult, Budapesten a dezindusztrializációs folyamat eredményeként az állomány abszolút értékben is csökkent (22 százalékról 9 százalékra). Az újraiparosodás egyértelmủ nyertese a Nyugat-Dunántúl, zömmel a jármügyártáshoz kapcsolódóan, s e régió aránya az ágazati müködőtőkéből 18,5 százalékról közel 35 százalékra ugrott! Növelte telephelyi vonzerejét Észak-Alföld is, ahol 10-röl 12,5 százalékra nőtt az ipari FDI aránya (Lux [2017a]).

A térbeli megjelenést és szétterülést már a korai évektől a következő fontosabb tényezők befolyásolták: a telephely földrajzi elhelyezkedése, a szűkebb-tágabb környezet gazdasági fejlettsége, a helyi gazdaság szerkezete, az elérhetőség, a lokális és regionális piac mérete és szerkezete, a helyi szereplőkkel való együttmüködés lehetösége, a helyi társadalmi tőke, valamint a városi központok funkcionális gazdagsága (Lux [2017]). A földrajzi telepítőtényezők sorában a főváros és nagyvárosok közelsége, a nyugat-európai piacokhoz, értékláncokhoz való közelség mellett a nyugati határ menti települések kedvezőbb pozíciója figyelhető meg.

Az 1990 utáni kormányzati gazdaságpolitika egyértelműen hatott az FDI ágazati és területi szerkezetének alakulására: a vidéki terek megújulásában - a feldolgozóipari munkahelyek létesítésében és ezen keresztül egyes térségek globális munkamegosztásba való bekapcsolásában - egyre hangsúlyosabbá vált a külföldi müködőtőke szerepe. Mindennek ellenére a külföldi müködőtőke nem csökkentette a regionális különbségeket, sőt inkább növelte azokat, mivel a külföldi érdekeltségü cégek nem tudták magukkal húzni a hazai tulajdoni többségü kis- és közepes vállalatokat, amelyek továbbra sem javítottak érdemben a versenyképességükön (Hunya [2014]).

A beruházások volumenindexei nemzetgazdasági szinten követték a gazdaság ciklusait, azaz a beruházások és a GDP növekedése között nemzetgazdasági szinten szoros a korreláció. A beruházások, a tőkeállomány térbeli eloszlása és a gazdasági növekedés közötti kapcsolat makro- és szubnacionális szinten is igazolható. A megyei szintű alakulásukban már egyedi tényezők (ipari vagy infrastrukturális nagyberuházások időzítése és lefutása, külföldi működőtőke- vagy kormányzati beruházás) is jelentős szerepet játszana.

A beruházások területi eloszlását tekintve 2002 óta folyamatosan az ÚJRAIPAROsoDó megyék álltak az élen, nem pedig a - beruházások tekintetében erős fluktuációt mutató - FDI fELDOLGOzóiPARI megyék (Lengyel-Varga [2018]). Az utóbbi megyecsoportban az újra befektetett FDI csökkenő aránya, illetve az osztalék hazautalása (profitkivonás) is magyarázza a beruházások fluktuációját. E megyék 2014-2015-ben kimagasló értéket értek el (valószínűleg az autópálya-építések miatt is), de az FDIbefektetések e megyéket is célpontként választották. A beruházások a többi három megyetípusban (CENTRUM, TUDÁsKÖZPONT, RURÁLIS) visszaesést mutatnak, ciklikus jellegük függ az EU-források kimerülésétől. 2013-2015 között az építőipari beruházások szerepe kimagasló, ami az EU-forrásokra épülő állami és magánberuházásokat jelzi. A korábbi évekre az erős költségvetési beruházási expanzió helyét 2014-et követően a feldolgozóipari beruházási expanzió vette át (újraiparosítási kormányzati program). A beruházások alakulásában - hasonlóan az FDI-hez - a feldolgozóipar szerepe 
meghatározó, s egy-egy nagyberuházás dominanciája és az ezektől való függőség bizonyos sérülékenységet jelez. Ugyanakkor a külföldi nagyvállalatok beágyazottsága a hazai gazdaságba (például beszállítói hálózatok révén) messze elmarad az előzetes várakozásoktól. Az évtized közepére Közép-Dunántúlról Fejér, a Nyugat-Dunántúlról Györ-Moson-Sopron is belépett a feldolgozóipar vezérelte pályára, miközben az iparvezérelt növekedési pálya térben határozottan „szétterült”. E csoportba sorolhatjuk Veszprém, Bács-Kiskun, Jász-Nagykun-Szolnok megyét.

A beruházások hosszabb távon fejtik ki hatásukat a gazdasági növekedésre, de ez a közel másfél évtizedes időszak is jelzi a megyetípusok közötti tartós eltéréseket és a Centrum visszaesését. Ugyanakkor a beruházási adatok azt sugallják, hogy még 2014-2016 között is eléggé volatilisen alakult a beruházási tevékenység ágazatok és évek szerint, szinte nincs olyan, ahol három egymást követö évben növekedés, föleg egyenletes növekedés kimutatható volna.

\section{A külföldi müködőtőke hatása a gazdasági növekedésre és a beruházásokra megyei szinten - empirikus elemzés}

A külföldi működőtőke gazdasági növekedésre, illetve a beruházásokra gyakorolt hatását vizsgáljuk a magyarországi megyékben. Ez utóbbit ökonometriai elemzéssel teszteljük, mivel feltételezhető, hogy a megyék fejlettsége és külföldi müködőtőkével való ellátottságuk közti összefüggés csak látszólagos. Az sem látszik az adatokból, hogy vajon az északnyugati és a központi megyék fejlettsége vonzotta-e a külföldi tőkét, vagy a külföldi tőke tette-e fejlettebbé ezeket a megyéket, esetleg mindkettö, vagyis e gondolatmenetnek megfelelően visszacsatolás van a külföldi tőke beáramlása és a megyék fejlettsége között, ami növeli a területi egyenlőtlenségeket. A következőkben az FDI és a gazdasági növekedés, illetve az FDI és a beruházások területi megoszlása közötti oksági kapcsolatot teszteljük megyei szinten.

\section{Módszer és adatok}

A magyar megyékre a 2000 és 2018 közötti időszakra állnak rendelkezésre éves gyakoriságú adatok. Az adatok a KSH Tájékoztatási adatbázisából származnak. A gazdasági teljesítményt a bruttó hazai termék (GDP) mutatja, ennek a piaci beszerzési áron számolt értékét használjuk az elemzésben. Az FDI megyei eloszlását a külföldi érdekeltségü vállalkozások befektetett külföldi tőkeállománya alapján számoljuk. A 2000-2012 közötti időszakra a fizetésimérleg-kézikönyv 5-ös (BPM5) változata szerint, 2013-tól a frissebb, 6-os változatával (BPM6) ${ }^{4}$ készült adatokat használjuk a külföldi közvetlen tőkebefektetéssel müködő vállalkozások külföldi tőkéjének meghatározásához. A módszertani váltás a megyei idősorokban nem okoz jelentős

\footnotetext{
${ }^{4} \mathrm{Az}$ áttérés a statisztikai módszertani számítás szempontjából lényeges.
} 
törést. A Hajdú-Bihar megyére vonatkozó adatokat kihagytuk az elemzésből az adatok magas fluktuációja miatt. ${ }^{5}$

Az országban a külföldi érdekeltségü vállalkozások befektetett külföldi tőkéje az ezredfordulós 5577 milliárd forintról - az újra befektetett tőkének és az utóbbi évek néhány jelentős feldolgozóipari beruházásának köszönhetően - 2014-ig növekedett (25 800 milliárd forint), ez az érték 2016-ra 23656 milliárd forintra csökkent. A csökkenést a fövárosi folyamatok önmagukban magyarázzak, vidéken még nem látszik ilyen fordulat. A GDP éves összértékében is hasonló növekvő trend figyelhető meg az ezredfordulós 13350 milliárd forintról 2016-ra 35474 milliárd forintra. A megyék közötti eloszlás az 5. ábrán látható. Budapest mindkét mutatójában (GDP és FDI) messze meghaladja a megyei értékeket, mivel a külföldi vállalatok többségének székhelye Budapest.

Az 5. ábra mutatja, hogy az FDI erőteljesen koncentrálódik az északnyugati fejlettebb megyékben, elsősorban Györ-Moson-Sopron, Fejér és Pest megyében. A GDP értéke valamivel kiegyenlítettebb, ám a fejletlenebb, kisebb, illetve nagyvárossal nem rendelkező megyék itt is jóval alacsonyabb értékeket mutatnak. A megyei GDP és FDI éves változásait vizsgálva erős korreláció figyelhető meg e két mutató között, a korrelációs koefficiens értéke 0,97. Ez azonban nem jelez semmilyen okságot a két változó között. Ha azonban egyszerü lineáris regressziós egyenlet felállításával csak az FDI GDP-re gyakorolt hatását vizsgálnánk, az hamis regresszió lehet több okból is:

- feltételezzük, hogy a GDP (mint a gazdasági teljesítmény egyfajta méröszáma) is visszahat az FDI-re;

- a korrelációt valamilyen harmadik fejlettségi tényező (például infrastrukturális fejlettség, pénzügyi fejlettség, technológiai fejlettség, gazdasági környezet) okozza, amely a GDP-re és az FDI-re is hatással van;

- a GDP és az FDI megyénkénti idősorai időbeli trendet tartalmaznak, és nem stacionerek.

\section{Oksági vizsgálat}

Az FDI és a gazdasági növekedés összefüggésének vizsgálatához a Granger-okságtesztet használtuk. ${ }^{6}$ A stacionaritás problémáját Dickey-Fuller- (ADF) teszttel szürtük ki. Elöször a két változó közötti kapcsolatot idősor-modellezéssel elemezzük. Ennek előnye, hogy vizsgálható az ok-okozati kapcsolat, mivel az ok minden esetben megelözi az okozatot. Az okságvizsgálathoz szükség van arra, hogy az idősorok stacionerek legyenek. A teszt eredményeiből arra következtethetünk, hogy a legtöbb megye esetében sem a GDP, sem az FDI idősora nem stacioner. A tesztek eredményei az 1. táblázatban szerepelnek.

5 A 2012-es 460 milliárd forintos FDI után 2013-ra 35 milliárd, majd 2014-re közel 700 milliárd forintos FDI-ről számolnak be, ami jelentősen torzítja az elemzés eredményeit.

${ }^{6}$ Két idősor elemzése során a Granger-féle oksági vizsgálat a leggyakrabban alkalmazott kauzalitástesztelési eljárás. A Granger-féle oksági vizsgálat abból a feltételezésből indul ki, hogy legyen $X$ változó Granger-értelemben oka $Y$ változónak, de $Y$ ne legyen Granger-értelemben oka $X$-nek (Granger [1969]). 
5. ábra

A nominális GDP, az FDI-befektetések (inflows) és a beruházások (INV) alakulása Magyarország megyéiben, 2000-2018 (milliárd forint)

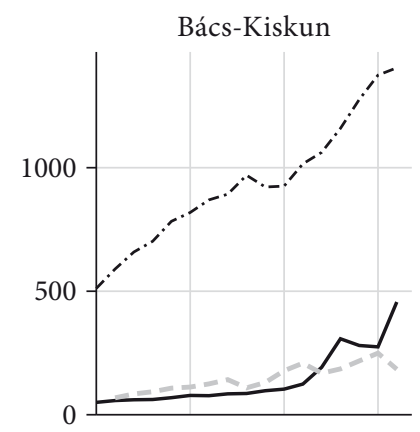

Borsod-Abaúj-Zemplén

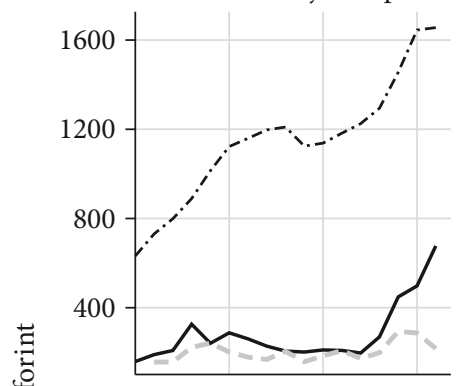

Fejér
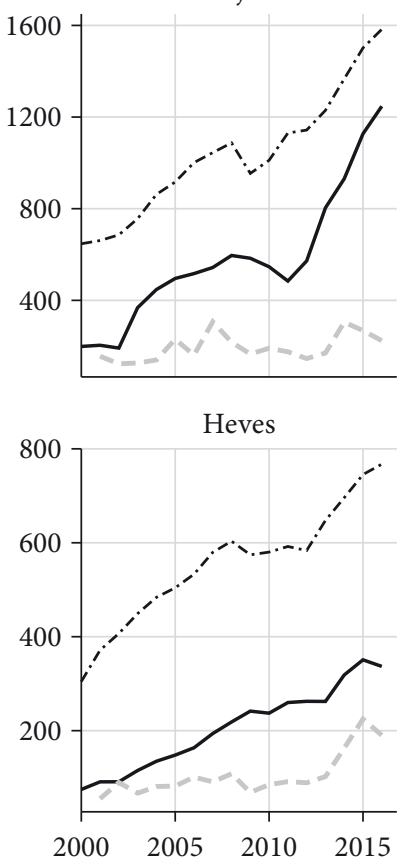

Baranya

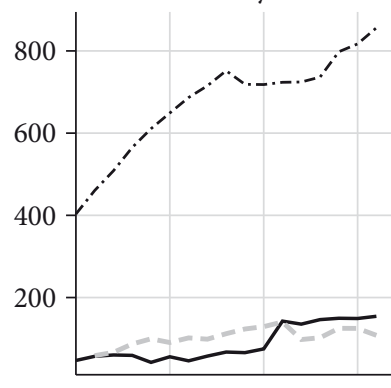

Budapest

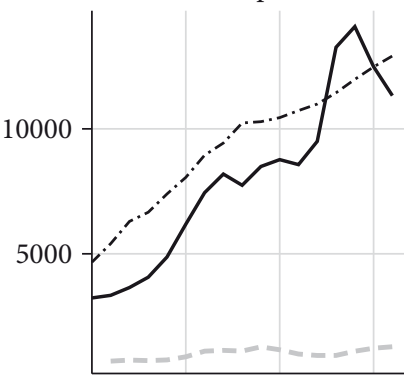

Győr-Moson-Sopron

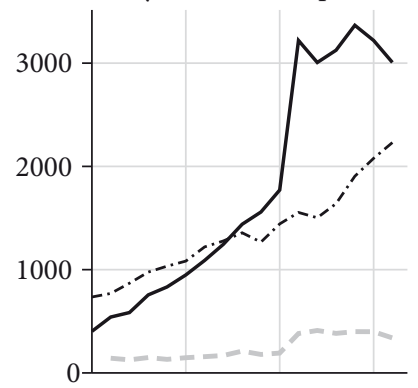

Jász-Nagykun-Szolnok

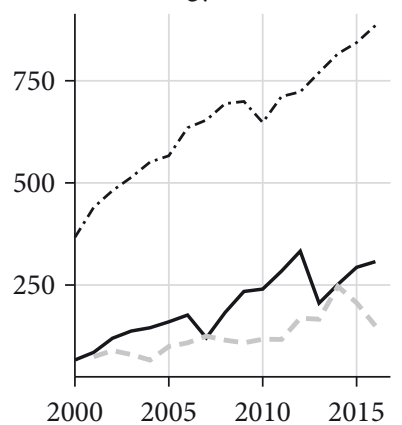

Békés

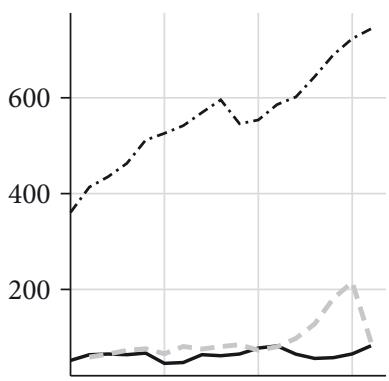

Csongrád

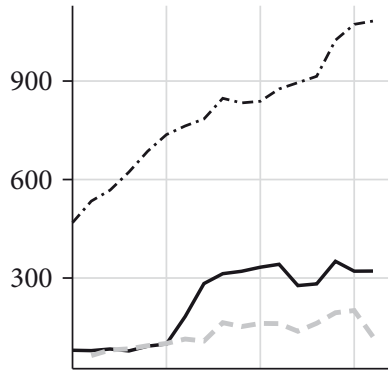

Hajdú-Bihar

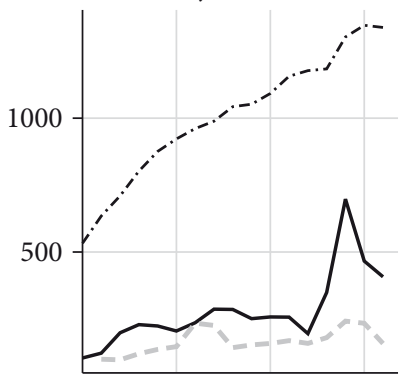

Komárom-Esztergom

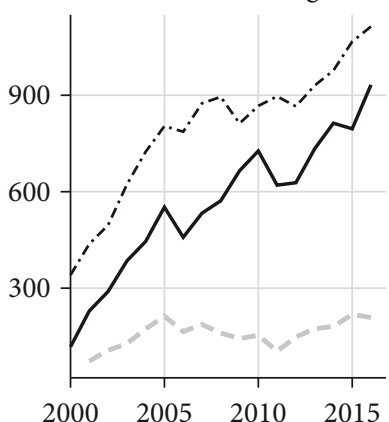

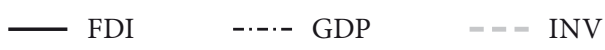


Az 5. ábra folytatása
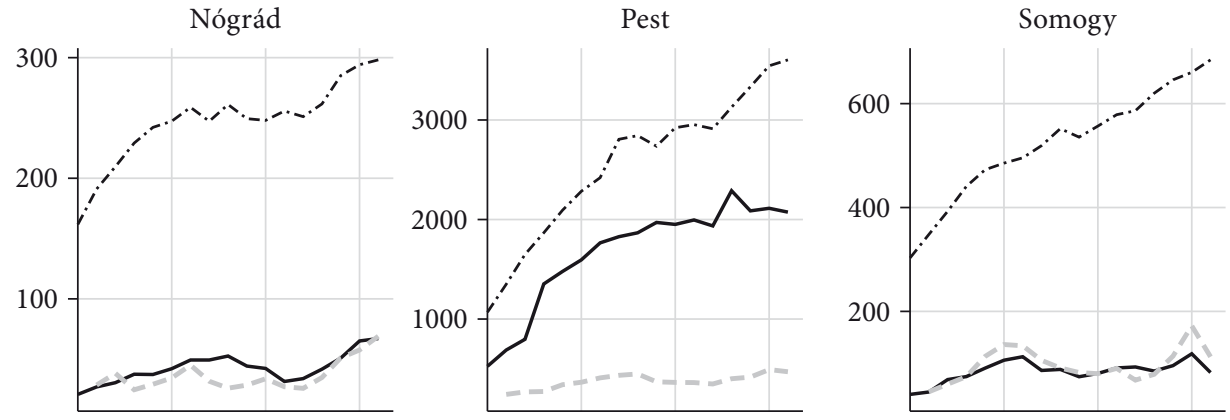

Szabolcs-Szatmár-Bereg

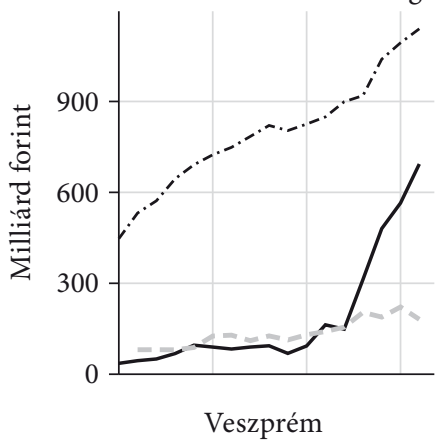

Tolna

Vas
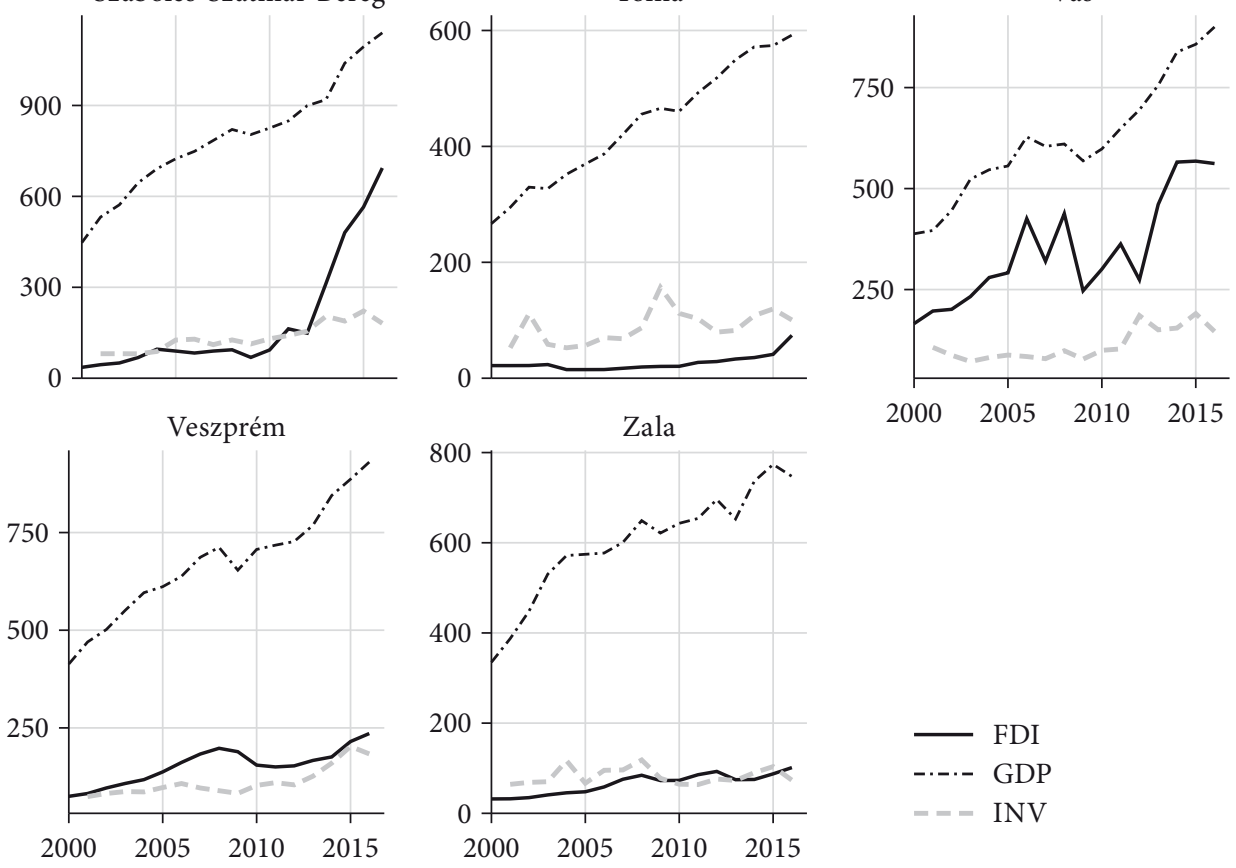

Forrás: KSH-adatbázis alapján Gyimesi András szerkesztése.

A GDP, illetve az FDI növekedési rátáját megvizsgálva és ezekre az idősorokra is megyénként elvégezve a stacionaritástesztet, azt kapjuk, hogy a növekedési ráták már minden megye esetében stacionáriusak. Így a továbbiakban a GDP és az FDI növekedési rátája közötti kapcsolatot elemezzük. A 6. ábrán ezeket a növekedési rátákat ábrázoltuk megyénként. 
1. táblázat

A Dickey-Fuller-féle és a Granger-oksági idősoros tesztek eredményei

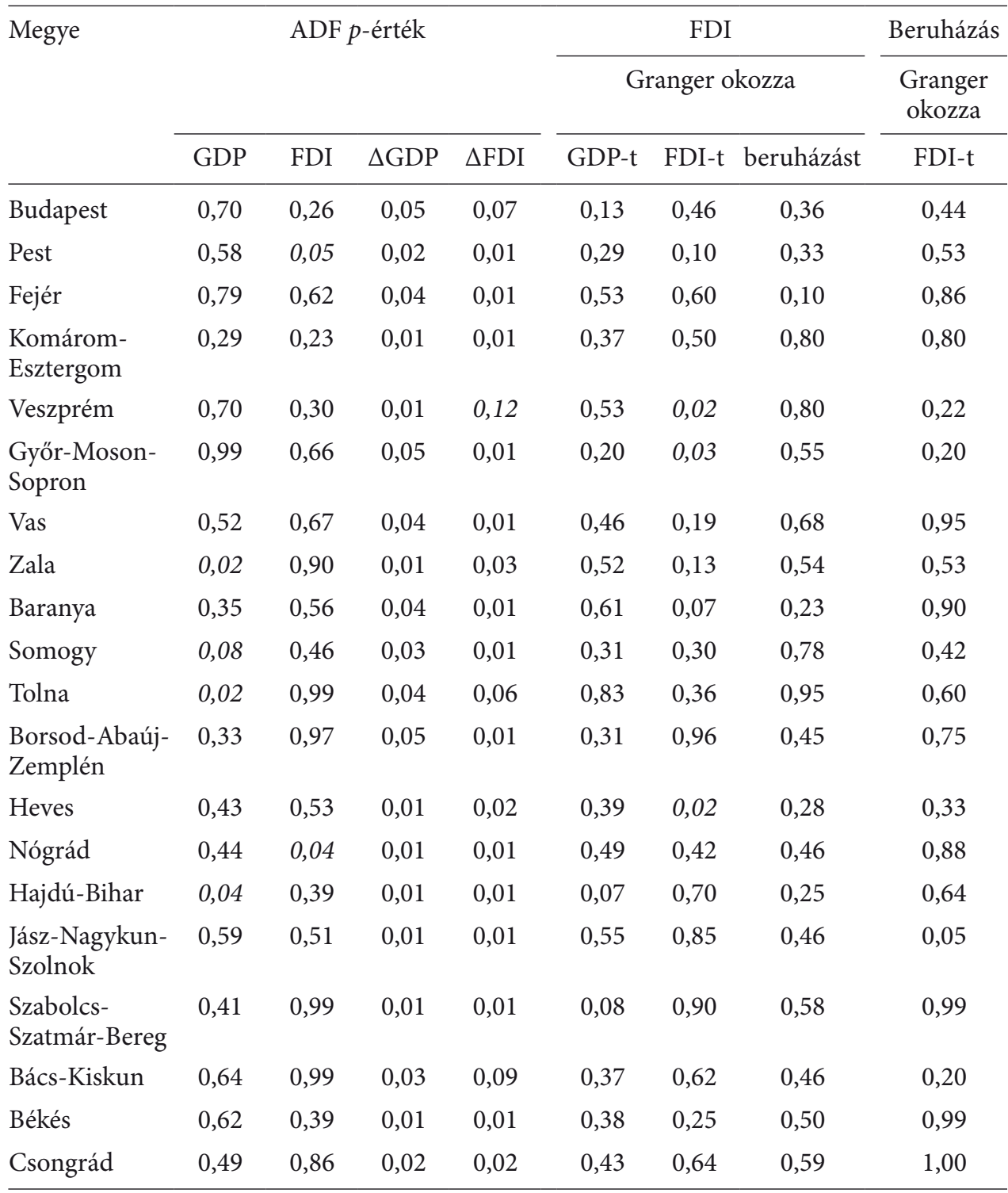

Megjegyzés: a táblázatban a tesztek p-értékei szerepelnek. Az ADF-teszteknél az alacsony p-érték arra utal, hogy az idősor stacioner. Ez a GDP, illetve az FDI idősorai közül csak néhányra igaz (dőlten). Míg a növekedési rátáknál lényegében mindegyik esetben alacsony a $p$-érték. A Granger-teszteknél az alacsony p-érték azt jelenti, hogy van Granger-okság az adott két változó között. Csak a GDP FDI irányába ható okságánál kapunk néhány 5 százalékos szinten szignifikáns értéket, a többi tesztnél nem. Ha a GDP növekedése a tényleges okozója az FDI növekedésének, akkor hosszabb idősor (több adat) esetén több megyében várható, hogy szignifikáns hatást kapnánk.

Forrás: saját szerkesztés. 
6. ábra

A GDP és az FDI növekedési rátájának alakulása Magyarország megyéiben, 2000-2018 (százalék)
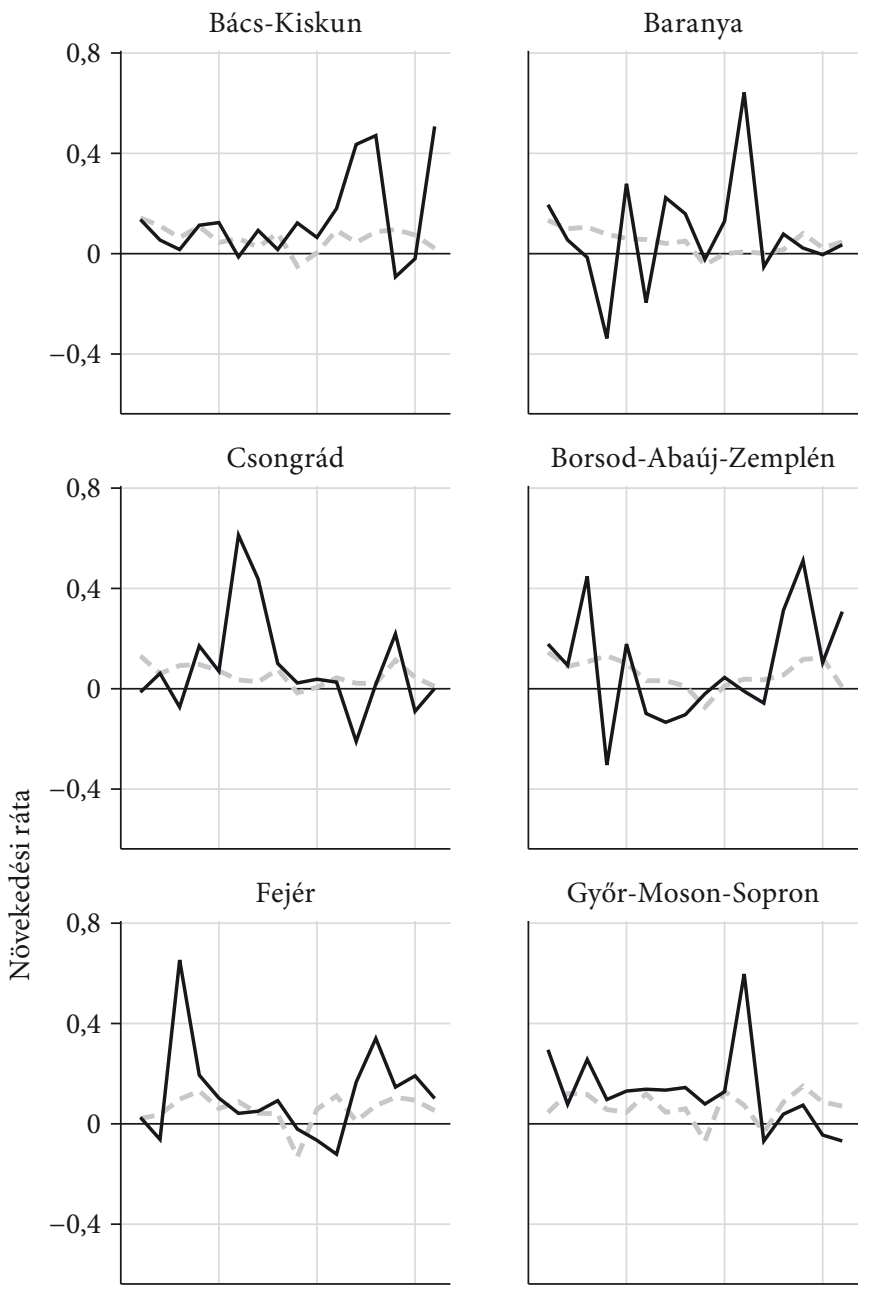

Borsod-Abaúj-Zemplén

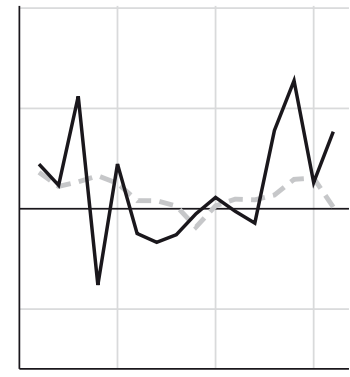

Győr-Moson-Sopron
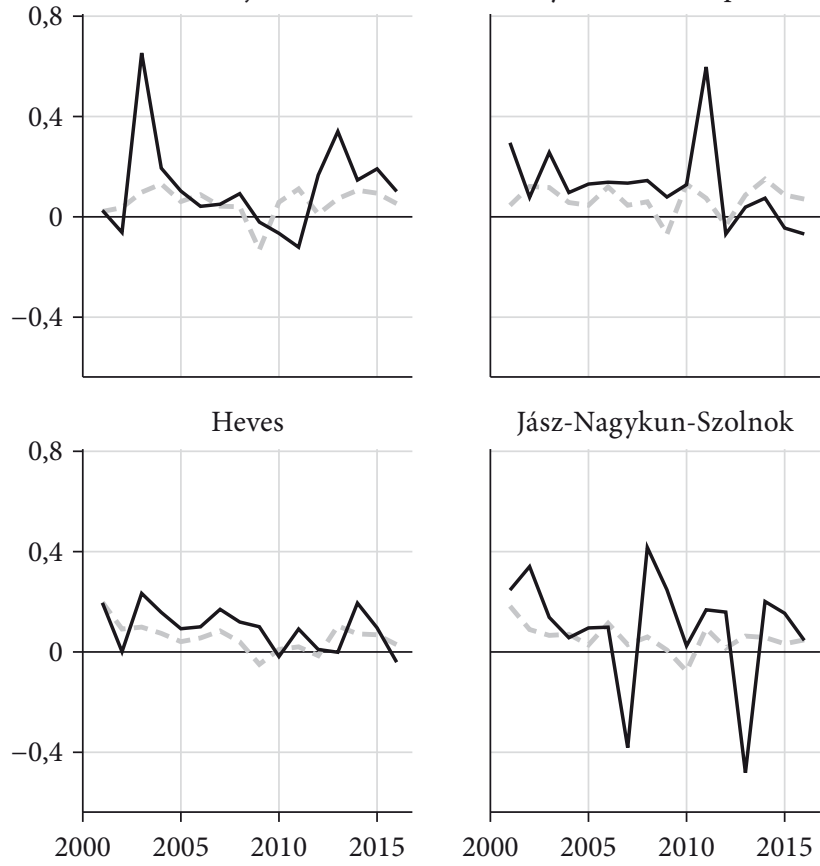

Jász-Nagykun-Szolnok

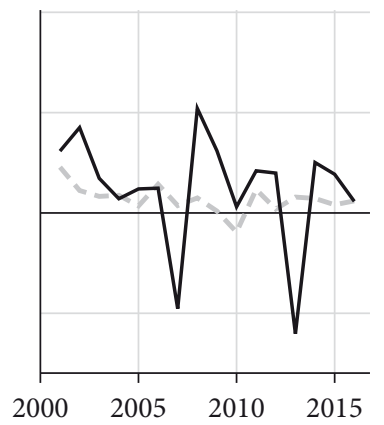

Békés

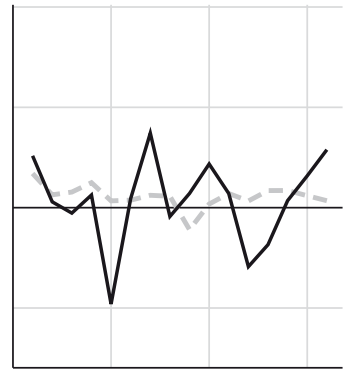

Budapest

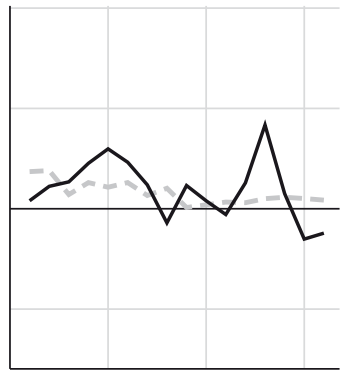

Hajdú-Bihar

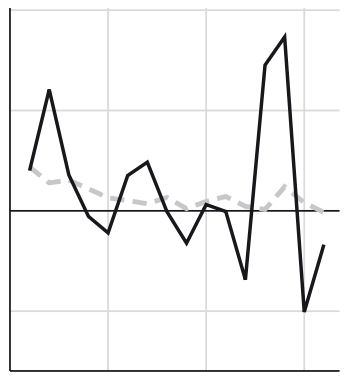

Komárom-Esztergom

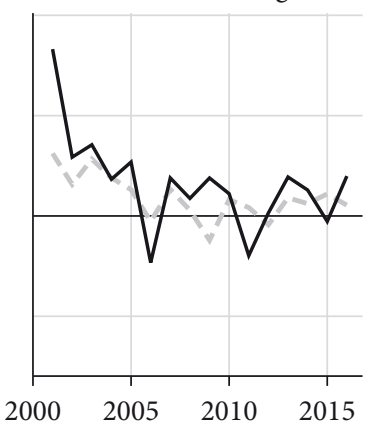

- FDI $\quad=--$ GDP 
A 6. ábra folytatása
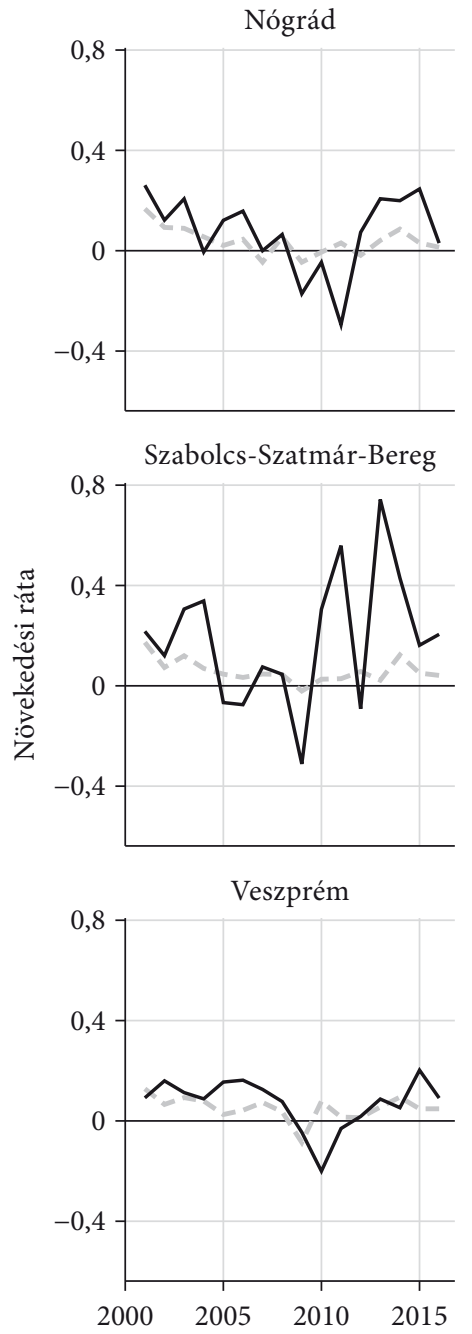

Pest

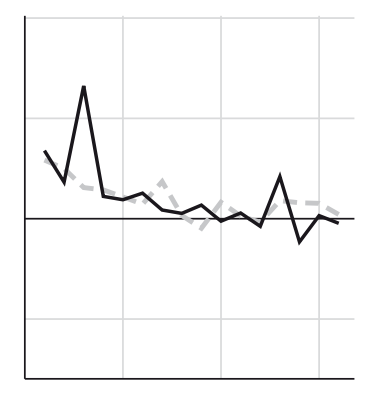

Tolna

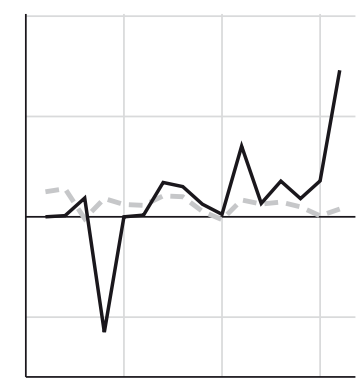

Zala

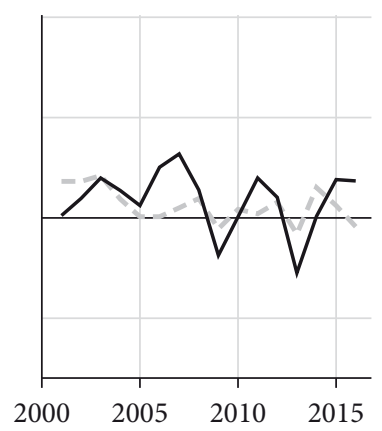

Somogy

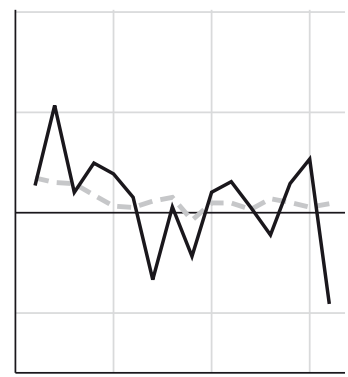

Vas

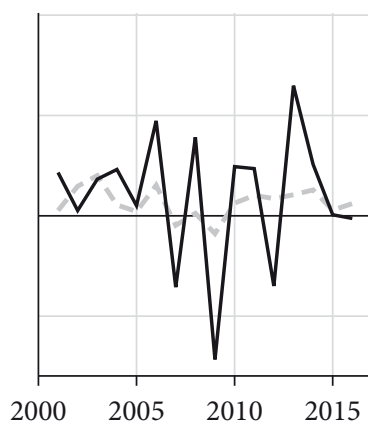

- FDI

GDP

Forrás: KSH-adatbázis alapján Gyimesi András szerkesztése.

A 6. ábra szerint a GDP és az FDI növekedési rátái között már nincs együtt mozgás. Az FDI növekedési rátájának ingadozásait nem követi a GDP növekedési trendje, ez utóbbi sokkal statikusabb.

A GDP és az FDI növekedési rátáira elvégezhető a Granger-oksági teszt, amivel azt vizsgáljuk, hogy az FDI adott évi, illetve korábbi értékei szignifikánsan hozzájárulnak-e a GDP következő évi előrejelzéséhez (majd fordítva, ekkor a GDP az ok és az FDI az okozat). Megyénként elvégezve a tesztet, két késleltetést alkalmazva, azt kapjuk, hogy 5 százalékos szinten az FDI-növekedés egyik megye esetében sem (Granger-)okozója a GDP növekedésének. A GDP okozati hatását vizsgálva az FDI-re már több megye esetében is szignifikáns kapcsolatot találtunk (1. táblázat). Mivel a megyei idősorok elég rövidek, ráadásul differenciált idősorokkal 
dolgozunk, megyénként igen kevés információ áll rendelkezésre, ezért célszerü az összes adaton egyben tesztelni az okságot. Ehhez használható az úgynevezett Granger-panelteszt. A teszt eredménye (2. táblázat) azt mutatja, hogy a megyékben valójában a GDP növekedési rátája Granger-oka az FDI növekedésének, míg fordítva nincs oksági kapcsolat.

\section{2. táblázat}

A Granger-oksági teszt eredményei

\begin{tabular}{ccccc}
\hline & \multicolumn{4}{c}{ Nullhipotézis } \\
\cline { 2 - 5 } & $\begin{array}{c}\text { az FDI nem } \\
\text { okozza a GDP-t }\end{array}$ & $\begin{array}{c}\text { a GDP nem } \\
\text { okozza az FDI-t }\end{array}$ & $\begin{array}{c}\text { az FDI nem okozza } \\
\text { a beruházást }\end{array}$ & $\begin{array}{c}\text { a beruházás nem } \\
\text { okozza az FDI-t }\end{array}$ \\
\hline$p$-érték & 0,8447 & 0,05863 & 0,316 & 0,2994 \\
\hline
\end{tabular}

Összességében az oksági tesztekből arra következtethetünk, hogy az FDI és a GDP közti korrelációt nem az FDI-beáramlás és annak feltételezett gazdasági növekedési hatása okozza. Az látszik, hogy inkább azokba a megyékbe áramlik több működőtőke, amelyek egyébként is fejlettebbek, és megtalálhatók a magasabb gazdasági növekedés más (endogén) tényezői is.

Az FDI feltételezhető pozitív hatásai között szerepel, hogy hatással van a helyi beruházások alakulására. Ezért megvizsgáltuk az oksági kapcsolatot a megyei beruházások összértéke és az FDI között is. Ezeknek a p-értékei láthatók az 1. táblázat utolsó két oszlopában. Az eredmények azt mutatják, hogy nem az FDI-növekedés okozza a beruházások növekedését. Ugyanakkor ez esetben fordított irányú oksági kapcsolat sem mutatható ki. Az FDI növekedése tehát nem eredményezi a helyi beruházások növekedését sem, ami összecseng azzal a ténnyel, hogy az FDI hozzájárulása az állóeszköz-beruházásokhoz Magyarországon és a régióban is csökkenő tendenciát mutat.

\section{Panelregressziós elemzések}

Az oksági tesztekből nem tudunk következtetni az FDI és a GDP között egyidejü (egy éven belüli) kapcsolatra. Ehhez nagyobb frekvenciájú adatokra lenne szükség egy olyan panelregresszióban, ahol a GDP az eredményváltozó, és az FDI magyarázó változójának a paramétere megadja az FDI egyidejü hatását a GDPre. A paraméterbecslést azonban torzíthatja, ha oda-vissza hatás van a két változó között, illetve az is, ha kihagyunk olyan változókat a modellből, amelyek mindkét változóval korrelálnak.

Az FDI és a GDP közötti egyidejű (egy éven belüli) kapcsolatot egyszerű legkisebb négyzetek (OLS) módszerével becsült paraméterek alapján a fix hatásokkal futatott modellel becsültük. ${ }^{7}$ A megyei fix hatásokkal kontrollálunk olyan tényezőkre, ame-

\footnotetext{
${ }^{7}$ A utóbbi probléma megoldásához segít, hogy a panelstruktúra lehetőséget ad arra, hogy megyei fix hatásokat, illetve év fix hatásokat szerepeltessünk a modellben. Ez lényegében annyi értékủ változó
} 
lyek megyénként különböznek, de időben állandók, vagy csak lassan változnak (például infrastrukturális fejlettség, gazdasági környezet), míg az év fix hatásokkal az egész országot érintő, megyénként egységes időbeli gazdasági ciklusokra (például pénzügyi válság). A regressziós modellekben a változók szintbeli értékeinek (nem növekedési ráták) természetes alapú logaritmusait szerepeltettük, mivel feltételezhető a multiplikatív kapcsolat (azt akarjuk megbecsülni, hogy ha 1 százalékkal változik az FDI, akkor hány százalékkal változik a GDP). A modellbe a két változó késleltetett értékeit is beemeltük, azért, hogy pontosabb legyen a log(FDI) változó paraméterbecslése, tehát a becsült egyidejü hatás.

A 3. táblázatban láthatók az egyszerü legkisebb négyzetek (OLS) módszerével becsült paraméterek (1) és a (2) oszlopban a fix hatásokkal futtatott modell paraméterbecslései. Látható, hogy a fixhatás-modellben jelentősen alacsonyabb a $\log (\mathrm{FDI})$ paraméterértéke, de még mindig pozitív szignifikáns hatást becsültünk. Még ebben a specifikációban sem vettük figyelembe, hogy a GDP visszahathat az FDI értékére az adott éven belül, tehát fennállhat az endogenitás problémája.

Ahhoz, hogy megkapjuk az FDI exogén hatását a GDP-re, használható az instrumentális változók módszere. Olyan változókat kell keresni, amelyek szoros kapcsolatban vannak az FDI-vel, viszont nem függnek a GDP adott évi értékétől. Mivel ilyen releváns változó nem állt rendelkezésre, ezért az FDI késleltetett értékét, a $\log$ (FDIlag1) változót használtuk instrumentumként. A kétlépcsős legkisebb négyzetek módszere (2SLS) első lépéseként megbecsültünk egy regressziót, ahol az eredményváltozó a $\log (\mathrm{FDI})$, és magyarázó változóként szerepel a $\log$ (FDIlag1), illetve a többi magyarázó változó a fixhatás-modellben is szerepelt. Ezután második lépésben a megbecsült $\log (\mathrm{FDI})$-értéket használtuk magyarázó változóként az eredeti modellben, ahol a $\log (\mathrm{GDP})$ az eredményváltozó. Erre a megbecsült $\log (\mathrm{FDI})$-re már nem hat vissza a $\log (\mathrm{GDP})$ értéke, mivel azt a késleltetett megfigyelések alapján becsültük, tehát exogénnek tekinthető. A 2SLS módszerrel becsült paraméterek alapján [lásd a 3. táblázat (3) oszlopát] már 10 százalékos szinten sem szignifikáns a $\log (\mathrm{FDI})$ paramétere, tehát a végső modell alapján nem találtunk bizonyítékot arra, hogy az FDI az adott éven belül hatással lenne a GDP-re. Ehhez az eredményhez szükség volt fix hatások beépítésére és az oda-vissza hatás kiküszöbölésére a modellben.

A (4) és (5) modellspecifikációban ugyanígy a fix hatások és a 2SLS módszerrel becsültük a regressziókat, ám itt kontrollváltozóként szerepel a megyei beruházások összértéke (INV) és ennek késleltetett értéke. Látszik, hogy a beruházások szerepeltetése a modellben tovább csökkenti az FDI hatásának szignifikanciáját. Ugyanakkor a beruházások hatása az adott évi GDP-re a várakozásoknak megfelelően pozitív előjelü és szignifikáns (7. ábra).

Lefuttattuk a regressziókat oly módon, hogy a GDP helyett a megyei beruházást szerepeltettük magyarázó változóként (4. táblázat). Ebben az esetben is hasonló eredményeket

(dummy), ahány megyénk és évünk van. A kétértékü változó értéke 1 , ha az adott megyéhez/évhez tartozik a megfigyelés, és 0 , ha nem. Ez lényegében azt mutatja, hogy a modellben szereplő konstans értéke függ-e az évtől és a megyétől. 
3. táblázat

A panelregressziók paraméterbecslései

Független változó: $\log (\mathrm{GDP})$

\begin{tabular}{|c|c|c|c|c|c|}
\hline & $\begin{array}{l}\text { OLS } \\
(1)\end{array}$ & $\begin{array}{l}\text { Fix hatás } \\
\text { (2) }\end{array}$ & $\begin{array}{l}2 \operatorname{SLS}^{a} \\
(3)\end{array}$ & $\begin{array}{l}\text { Fix hatás } \\
\text { (4) }\end{array}$ & $\begin{array}{l}2 \operatorname{SLS}^{a} \\
(5)\end{array}$ \\
\hline $\log (\mathrm{FDI})$ & $\begin{array}{l}0,085^{\star * *} \\
(0,016)\end{array}$ & $\begin{array}{l}0,031^{\star * *} \\
(0,012)\end{array}$ & $\begin{array}{c}0,020 \\
(0,012)\end{array}$ & $\begin{array}{l}0,019^{*} \\
(0,011)\end{array}$ & $\begin{array}{c}0,011 \\
(0,011)\end{array}$ \\
\hline $\log$ (FDIlag1) & $\begin{array}{l}-0,075^{\star * *} \\
(0,017)\end{array}$ & $\begin{array}{l}-0,009 \\
(0,012)\end{array}$ & & $\begin{array}{l}-0,007 \\
(0,012)\end{array}$ & \\
\hline $\log ($ GDPlag1) & $\begin{array}{l}0,978^{\star * *} \\
(0,008)\end{array}$ & $\begin{array}{l}0,733^{\star * *} \\
(0,036)\end{array}$ & $\begin{array}{l}0,734^{* * *} \\
(0,037)\end{array}$ & $\begin{array}{l}0,732^{\star * *} \\
(0,039)\end{array}$ & $\begin{array}{l}0,734^{* * *} \\
(0,040)\end{array}$ \\
\hline $\log (\mathrm{INV})$ & & & & $\begin{array}{l}0,037^{* * *} \\
(0,011)\end{array}$ & $\begin{array}{l}0,038^{* * *} \\
(0,011)\end{array}$ \\
\hline $\log ($ INVlag1) & & & & $\begin{array}{c}0,004 \\
(0,012)\end{array}$ & $\begin{array}{c}0,004 \\
(0,011)\end{array}$ \\
\hline Konstans & $\begin{array}{l}0,138^{* * *} \\
(0,037)\end{array}$ & & & & \\
\hline Megye fix hatás & nem & igen & igen & igen & igen \\
\hline Év fix hatás & nem & igen & igen & igen & igen \\
\hline Megfigyelések száma & 304 & 304 & 304 & 285 & 285 \\
\hline$R^{2}$ & 0,995 & 0,676 & 0,675 & 0,682 & 0,681 \\
\hline Kiigazított $R^{2}$ & 0,995 & 0,632 & 0,632 & 0,634 & 0,635 \\
\hline $\begin{array}{l}\text { Reziduális standard } \\
\text { hiba }\end{array}$ & $\begin{array}{c}0,053 \\
(\mathrm{df}=300)\end{array}$ & & & & \\
\hline$F$-próba & $\begin{array}{c}21146,240^{\star * *} \\
(\mathrm{df}=3 ; 300)\end{array}$ & $\begin{array}{c}185,538^{\star *} \\
(\mathrm{df}=3 ; 267)\end{array}$ & $550,100^{\star * \star}$ & $\begin{array}{c}105,874^{* * *} \\
(\mathrm{df}=5 ; 247)\end{array}$ & $527,519^{\star \star \star}$ \\
\hline
\end{tabular}

${ }^{a}$ Instrumentális változó az FDI késleltetett értéke (FDIlag1).

${ }^{*} p<0,1 ;{ }^{* *} p<0,05 ;{ }^{* *} p<0,01$.

kapunk, mint az előbbiben. Az OLS módszer esetén még erősen szignifikáns a paraméter, mivel a beruházások és az FDI között is van korreláció. A (3) oszlopban azonban látható, hogy ha 2SLS módszerrel kezeljük az oda-vissza hatást, akkor már 10 százalékos szinten sem lesz szignifikáns az FDI hatása a beruházásokra.

Az ökonometriai elemzés alapján arra következtethetünk, hogy a magyarországi megyékben a külföldi müködőtőke-befektetések az adott évben nincsenek pozitív szignifikáns hatással a megyei GDP-re. A Granger-oksági teszt alapján egyetlen megye esetében sem, illetve országos szinten sem támasztható alá, hogy a külföldi müködőtőke-befektetések növekedése növelné a GDP-t. Ellenben fordított esetben több megyében is és országos szinten is szignifikáns oksági hatás mutatkozott. Tehát leginkább a fejlettebb (és a magasabb GDP-növekedésü) megyékbe áramlik nagyobb menynyiségű külföldi müködőtőke. A beruházások volumenének szerepeltetése a modellben eltünteti az FDI szignifikáns pozitív hatását. A megyei beruházások (kormányzati és 


\section{7. ábra}

A beruházások és az GDP növekedési rátájának alakulása Magyarország megyéiben, 2000-2018 (százalék)

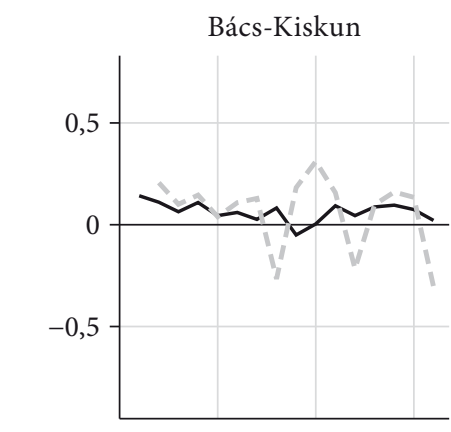

Borsod-Abaúj-Zemplén

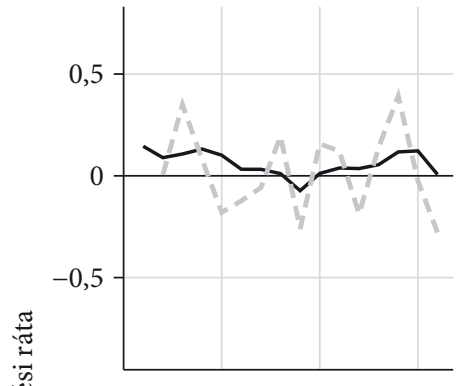

Fejér

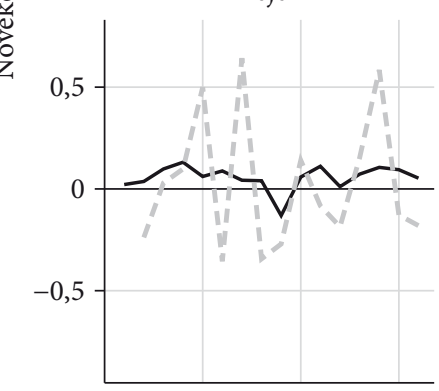

Heves

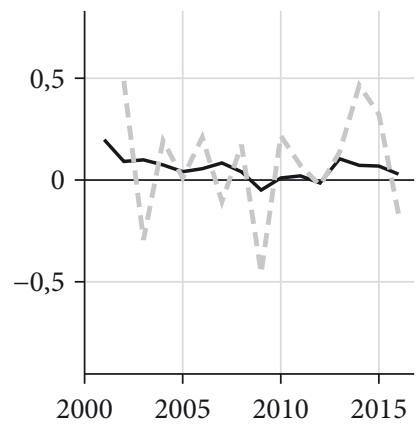

Baranya

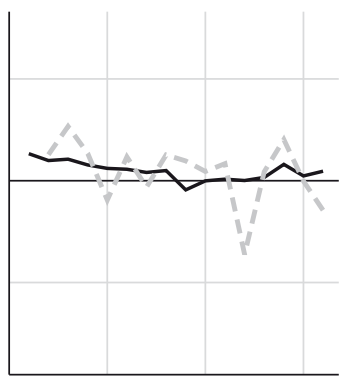

Budapest

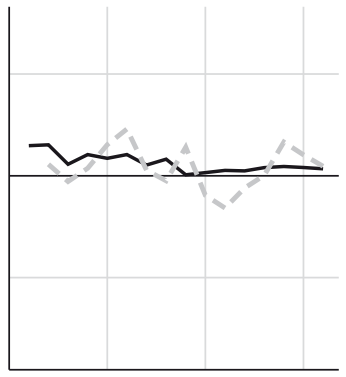

Győr-Moson-Sopron

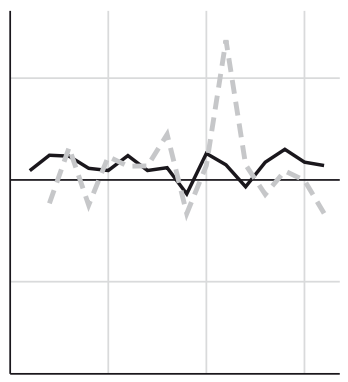

Jász-Nagykun-Szolnok

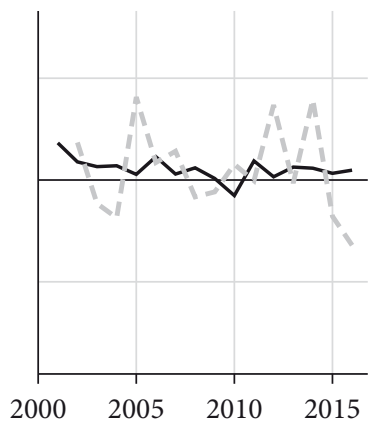

Békés

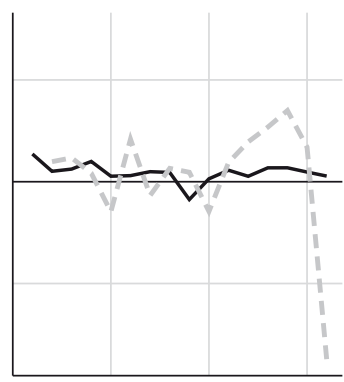

Csongrád

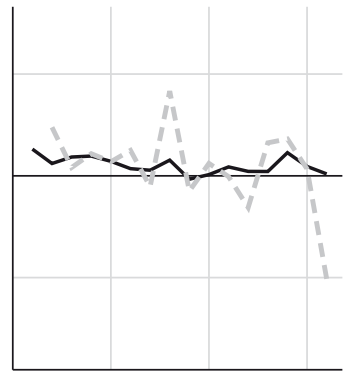

Hajdú-Bihar

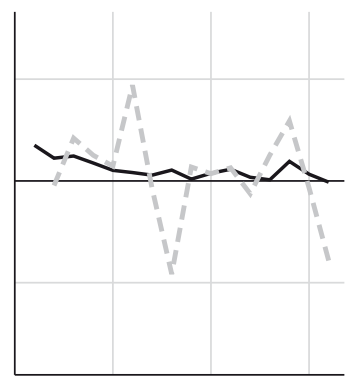

Komárom-Esztergom

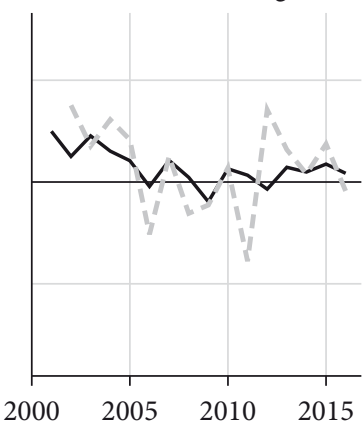


A 7. ábra folytatása
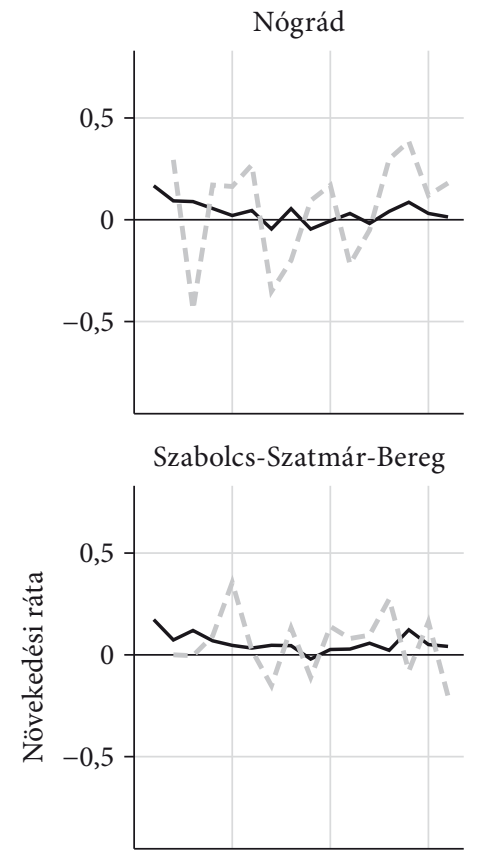

Veszprém

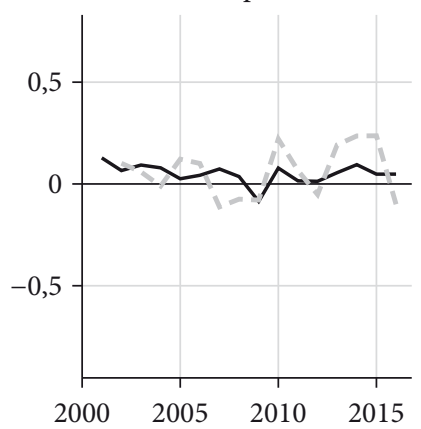

Pest

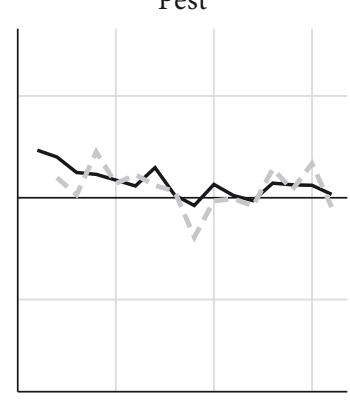

Tolna

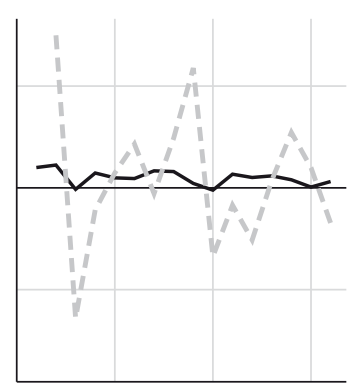

Zala

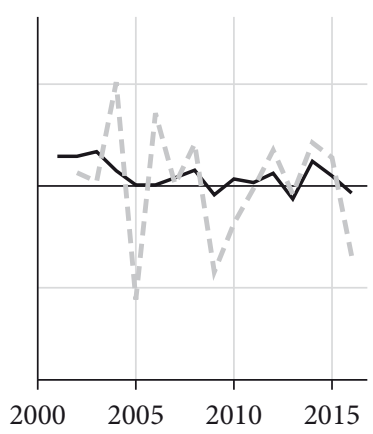

Somogy

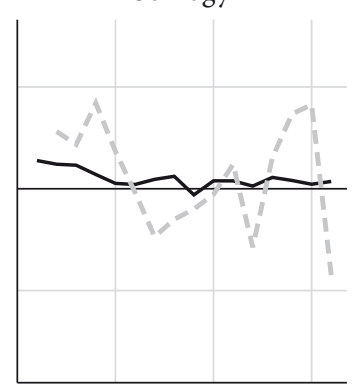

Vas

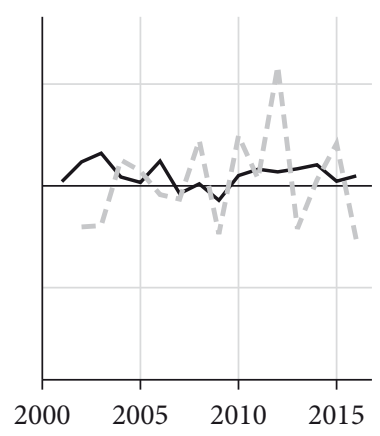

$\triangle \mathrm{GDP}$

Forrás: KSH-adatbázis alapján Gyimesi András szerkesztése

EU-s források, esetleg hazai magánberuházások) - úgy tűnik - jóval nagyobb szerepet játszanak a GDP alakításában, mint a külföldi működőtőke.

Összefoglalva megállapítható, hogy a külföldi tőke területi koncentrációjának okai elsősorban abban ragadhatók meg, hogy a CENTRUM megyékben, valamint az FDI FELDOLGOZÓIPARI közép- és nyugat-dunántúli régiókban kedvezőbbek a gazdasági adottságok, az infrastrukturális feltételek, kedvezőbb a földrajzi elhelyezkedésük, jobb minőségü munkaerő áll rendelkezésre, és az üzleti környezet (területi tőke), illetve a jogi-intézményi háttér is jobban segíti a megtelepedést, mint az ország más térségeiben. Ezek a kedvező feltételek a három legfejlettebb régióba vonzzák a külföldi tőkét, amely megtelepedésével kumulatív hatásként erősíti a pozitív agglomerációs externáliákat, így azok még vonzóbbá válnak a külföldi tőke számára az ország többi 
4. táblázat

A beruházásokra futtatott panelregressziók paraméterbecslései

Független változó: $\log (\mathrm{INV})$

\begin{tabular}{lccc}
\hline & $\begin{array}{c}\text { OLS } \\
(1)\end{array}$ & $\begin{array}{c}\text { Fix hatás } \\
(2)\end{array}$ & $\begin{array}{c}2 \text { SLS }^{a} \\
(3)\end{array}$ \\
\hline $\log (\mathrm{FDI})$ & $0,198^{\star * *}$ & $0,165^{* *}$ & 0,076 \\
& $(0,068)$ & $(0,064)$ & $(0,055)$ \\
$\log$ (FDIlag1) & $-0,121^{*}$ & $-0,070$ & \\
& $(0,068)$ & $(0,067)$ & \\
$\log ($ INVlag1) & $0,812^{* * *}$ & $0,480^{* * *}$ & $0,485^{* * *}$ \\
& $(0,034)$ & $(0,056)$ & $(0,057)$ \\
Konstans & $0,533^{* * *}$ & & \\
& $(0,098)$ & & \\
Megfigyelések száma & 285 & 285 & 285 \\
$R^{2}$ & 0,917 & 0,285 & 0,280 \\
Kiigazított $R^{2}$ & 0,916 & 0,185 & 0,182 \\
Reziduális standard hiba & $0,210(\mathrm{df}=281)$ & & \\
F-próba & $1036,320^{* * *}$ & $33,095^{* * *}$ & $92,305^{* * *}$ \\
& $(\mathrm{df}=3 ; 281)$ & $(\mathrm{df}=3 ; 249)$ & \\
\hline
\end{tabular}

${ }^{a}$ Instrumentális változó az FDI késleltetett értéke (FDIlag1).

${ }^{*} p<0,1 ;{ }^{* *} p<0,05 ;{ }^{* *} p<0,01$.

térségéhez képest. Mindeközben a déli országrészek, a RuRÁLIS és TudÁsközPONT megyék egyre jobban lemaradnak, hiszen nem tudják bevonzani a külföldi tőkét, és jelentős hazai vállalataik sincsenek, illetve a hazai tulajdoni többségü vállalatok nagy része nem tudja felvenni a versenyt a külföldiekkel. Ördögi kör alakul ki, ami tovább növeli Magyarországon a fejlettség területi különbségeit. Érzékelhető tehát, hogy a magyar gazdaság területi és tulajdonalapú dualitását csak tovább erősíti az FDI, ami azonban ténylegesen az egymást erősítő fejlettségbeli különbségek kumulatív és együttes hatásának a következménye.

\section{Összefoglalás}

A kelet-közép-európai országokban a gazdasági szerkezet átalakítása elsősorban a külföldi működőtőke-befektetéseken alapuló fejlesztési utat követte, ami rövid távon hozzájárult a termelékenység és a versenyképesség javulásához, de jelenleg mindkét tényező stagnál a kelet-közép-európai régióban. A szakirodalom egyetért azzal, hogy az FDI bármely pozitív hatása a növekedésre a fejlett országokban a legnagyobb, mivel azok képesek a külföldi befektetések hasznát learatni (Alfaro és szerzőtársai [2004]). A dominánsan külföldi működőtőkére építő, beruházásvezérelt piacgazdasági modellben a külföldi müködőtőke pozitív hatásai mind a beruházások, mind pedig 
a gazdasági növekedés tekintetében sokkal kevésbé érvényesülnek hosszabb távon (Mencinger [2003], Carkovic-Levine [2005], Gál-Schmidt [2017]).

Jelen tanulmány kiindulópontja Lengyel-Varga [2018] tanulmánya volt, amely a nemzetgazdasági növekedést a szubnacionális térségek növekedéséből vezeti le. Kutatásunk fó kérdése tehát az volt, hogy az FDI és a gazdasági növekedés, illetve a beruházások és az FDI közötti kapcsolat relevanciáját elemezzük a magyarországi megyék esetében.

Az FDI és a gazdasági növekedés közötti kapcsolatot területi szinten vizsgálva, a megyék fejlettsége és külföldi működőtőkével való ellátottságuk közötti összefüggés csak látszólagos. Empirikus elemzésünk alapján nem támasztható alá, hogy a külföldi müködőtőke-befektetések növekedése okozná a GDP növekedését, ugyanakkor leginkább a magasabb GDP-növekedéssel rendelkező megyékbe áramlik több külföldi működőtőke. A beruházások szerepeltetése is eltünteti a modellben az FDI szignifikáns pozitív hatását. A kormányzati és EU-forrás alapú beruházások jóval nagyobb szerepet játszanak a GDP alakításában, mint a külföldi müködőtőke. A térségek gazdasági növekedésében az FDI csak az egyik, de nem biztos, hogy a leglényegesebb növekedési faktor. A külföldi tőke területi koncentrációjának okait az FDI mellett a gazdasági-társadalmi adottságok, az infrastrukturális feltételek, a jobb földrajzi elhelyezkedés, a jobb minőségü munkaerö is meghatározza (Rodríguez-Pose [1998]). De még ezekben a relatíve fejlettebb térségekben is hiányoznak azok a tartós és innovatív növekedési tényezők, amelyek az endogén fejlődés, illetve az innovációvezérelt felzárkózás feltételeinek megteremtéséhez szükségesek.

Lengyel-Varga [2018] rámutat arra a dilemmára, hogy önmagában a külföldi működőtőke növekedését néhány feldolgozóipari megye generálja, ahol a külföldi müködőtőke beruházásain kívül a többi növekedési tényező alig hat. Ugyanis ezekben a megyékben az innovatív, tartós és fenntartható növekedés tényezői (kutatók, $\mathrm{K}+\mathrm{F}$, szabadalmak, diplomások, innovatív hazai vállalkozások) hiányoznak, így a növekedés ezekben a megyékben is időleges. Ugyanakkor a Granger-oksági vizsgálatunkból egyértelmủen látszik, hogy e térségek az eleve magasabb fejlettségi szint, valamint a nyugat-európai értékláncokhoz/piacokhoz való földrajzi közelség miatt váltak igen korán vonzóvá a külföldi müködőtőke számára. Kutatásunk is felhívja a figyelmet a Lengyel-Varga [2018] tanulmány egyik legfontosabb megállapítására, nevezetesen arra, hogy tartós és endogén növekedési tényezők hiányában a külföldi kapacitásnövelö beruházások önmagukban nem biztosítják a térségek hosszú távú és fenntartható növekedését.

\section{Hivatkozások}

Alfaro, L.-Chanda, A.-Kalemli-Ozcan, S.-Sayek, S. [2004]: FDI and economic growth: The role of local financial markets. Journal of International Economics, Vol. 64. No. 1. 89-112. o. https://doi.org/10.1016/s0022-1996(03)00081-3.

Antalóczy Katalin-Sass Magdolna [2005]: A külföldi müködőtőke-befektetések regionális elhelyezkedése és gazdasági hatásai Magyarországon. Közgazdasági Szemle, 52. évf. 5. sz. 494-520. o. 
Ashraf, A.-Herzer, D.-Nunnenkamp, P. [2016]: The effects of greenfield FDI and crossborder M\&As on total factor productivity. World Economy, Vol. 39. No. 11. 1728-1755. o. https://doi.org/10.1111/twec.12321.

Bailey, D.-Lenihan, H.-De Ruyter, A. [2016]: A cautionary tale of two 'tigers': Industrial policy 'lessons' from Ireland and Hungary? Journal of the Local Economy, Vol. 31. No. 8. 873-891. o. https://doi.org/10.1177/0269094216677779.

Bajo-Rubio, O.-Díaz-Mora, C.-Díaz-Roldán, C. [2010]: Foreign direct investment and regional growth: An analysis of the Spanish case. Regional Studies, Vol. 44. No. 3. 373-382. o. https://doi.org/10.1080/00343400802508844.

Balatoni András-Pitz Mónika [2012]: A működőtőke hatása a bruttó nemzeti jövedelemre Magyarországon. Közgazdasági Szemle, 59. évf. 1. sz. 1-30. o.

BARTA GYÖRgYi [2005]: The role of foreign direct investment in the spatial restructuring of hungarian industry. Megjelent: Barta Györgyi-G. Fekete Éva-Szörényiné Kukorelli IrénTimár Judit (szerk.): Hungarian Spaces and Places: Patterns of Transition. MTA Közgazdaság- és Regionális Tudományi Kutatóközpont Regionális Kutatások Intézete, 143-161. o.

Barta Györgyi-Kukely György-Lengyel Balázs-SÁGvári Bence [2007]: Magyarország a globális $\mathrm{K}+\mathrm{F}$ térképen. Fejlődő országok a multinacionális vállalatok változó $\mathrm{K}+\mathrm{F}$ stratégiájában. Tér és Társadalom, 21. évf. 3. sz.31-50. o. http://epa.oszk.hu/02200/02251/00028/ pdf/EPA02251_Ter_es_tarsadalom2241.pdf.

BAtTEN, J. A.-Vo, X. V. [2009]: An analysis of the relationship between foreign direct investment and economic growth. Applied Economics, Vol. 41. No. 13. 1621-1641. o. https://doi. org/10.1080/00036840701493758.

BÉLYÁCz IvÁN-Kuti Mónika [2009]: Külföldi működőtőke és külső eladósodás. Közgazdasági Szemle, 56. évf. 2. sz. 133-154. o.

Bermejo Carbonell, J.-Werner, R. [2018]: Does Foreign Direct Investment Generate Economic Growth? A New Empirical Approach Applied to Spain. Economic Geography, Vol. 94. No. 4. 425-456. o. https://doi.org/10.1080/00130095.2017.1393312.

Blomström, M.-Koкко, A. [1997]: How foreign investment affects host countries. Policy Research Working Paper Series, No. 1745. The World Bank, Washington. http://documents. worldbank.org/curated/en/992201468765633696/pdf/multi-page.pdf.

Blomström, M.-Koкко, A. [1998]: Multinational corporations and spillovers. Journal of Economic Surveys, Vol. 12. No. 3. 247-277. o. https://doi.org/10.1111/1467-6419.00056.

Blomström, M.-Lipsey, R.-Zejan, M. [1994]: What Explains Developing Country Growth? NBER Working Paper, No. 4436. https://doi.org/10.3386/w4132.

Borensztein, E.-De Gregorio, J.-Lee, J.-W. [1998]: How does foreign direct investment affect economic growth? Journal of International Economics, Vol. 45. No. 1. 115-135. o. https://doi.org/10.1016/s0022-1996(97)00033-0.

Buch, C.-Kokta, R.-Piazolo, D. [2003]: Does the East get what would otherwise flow to the South? Kiel Working Paper, No. 1061. https://doi.org/10.1016/s0147-5967(02)00013-6.

Campos, N. F.-Kinoshita, Y. [2002]: Foreign Direct Investment as Technology Transferred: Some Panel Evidence from the Transition Economies. The Manchester School, Vol. 70. No. 3. 398-419. o.

Carkovic, M.-Levine, R. [2002]: Does Foreign Direct Investment Accelerate Economic Growth? University of Minnesota Working Paper. http://siteresources.worldbank.org/ INTFR/Resources/fdi.pdf.

Carkovic, M.-Levine, R. [2005]: Does foreign direct investment accelerate economic growth? Megjelent: Moran, T. H.-Graham, E. M.-Blomström, M. (szerk.): Does foreign 
direct investment promote development? Institute for International Economics, Washington, DC. 195-220. o.

Casi, L.-Resmini, L. [2017]: Foreign direct investment and growth: Can different regional identities shape the returns to foreign capital investments? Environment and Planning, C, Politics And Space, Vol. 35. No. 8. 1483-1508. o. https://doi.org/10.1177/2399654417690906.

Chowdhury, A.-Mavrotas, G. [2006]: FDI and Growth: What Causes What? World Economy, Vol. 29. No. 1. 9-19. o. https://doi.org/10.1111/j.1467-9701.2006.00755.x.

Cooke, P. [2002]: Knowledge Economies. Clusters, Learning and Cooperative Advantage. Routledge, London.

De Mello, L. R. [1999]: Foreign direct investment-led growth. Evidence from time series and panel data. Oxford Economic Papers, Vol. 51. No. 1. 133-151. o. https://doi.org/10.1093/ oep/51.1.133.

Dixon, W. J.-Boswell, T. [1996]: Dependency, disarticulation, and denominator effects: Another look at foreign capital penetration. American Journal of Sociology, Vol. 102. No. 2. 543-562. o. https://doi.org/10.1086/230956.

Domar, E. D. [1947]: Expansion and employment. American Economic Review, Vol. 31. No. 1. 34-55. o. http://piketty.pse.ens.fr/files/Domar1947.pdf.

Dомві Áкоs [2013]: The Sources of Economic Growth and Relative Backwardness in the Central Eastern European Countries between 1995 and 2007. Post Communist Economies, Vol. 25. No 4. 425-444. o. https://doi.org/10.1080/14631377.2013.844927.

Feldstein, M.-Horioka, C. [1980]: Domestic Saving and International Capital Flows. The Economic Journal, Vol. 90. 314-329. o. https://doi.org/10.2307/2231790.

GÁl ZoLTÁn [2013]: Role of financial sector FDI in regional imbalances in Central and Eastern Europe. Megjelent: Gostyńska, A.-Tokarski, P. (szerk.): Eurozone enlargement: challenges for the V4 countries. The Polish Institute of International Affairs, Varsó, 19-30. o.

Gál Zoltán [2014]: Relocation of business services into Central and Eastern Europe (evidence from trade and location statistics). Romanian Review of Regional Studies, Vol. 10. No. 1. 67-78. o.

Gál Zoltán-JuHÁsz BÁLINT [2016]: A vállalatok nemzetköziesedésének vizsgálata KeletKözép-Európában makrogazdasági módszerekkel. Vezetéstudomány, 47. évf. 8. sz. 26-39. o.

Gál Zoltán-Schmidt Andrea [2017]: Geoeconomics in Central and Eastern Europe: Implications on FDI. Megjelent: Mark Munoz, J. (szerk.): Advances in Geoeconomics. Routledge, 76-93. o.

Gourinchas, P.-O.-JEanne, O. [2013]: Capital flows to developing countries: The allocation puzzle. Review of Economic Studies, Vol. 80. No. 4. 1484-1515. o. https://doi.org/10.1093/ restud/rdt004.

Granger, C. W. J. [1969]: Investigating Causal Relations by Econometric Models and Crossspectral Methods. Econometrica, Vol.37. No. 3.424-438. o. https://doi.org/10.2307/1912791.

Greenaway, D.-Görg, H. [2001]: Foreign Direct Investment and Intra-Industry Spillovers. Paper presented at the UNECE/EBRD Expert Meeting on Financing for Development: Enhancing the benefits of FDI and improving the flow of corporate finance in the transition economies. Genf, december 3.

Grossman, G.-Helpman, E. [1991]: Trade, knowledge spillovers, and growth. European Economic Review, Vol. 35. No. 2-3. 517-526. o. https://doi.org/10.1016/0014-2921(91)90153-a.

Hardy, J. [1998]: Cathedrals in the Desert? Transnationals, Corporate Strategy and Locality in Wroclaw. Regional Studies, Vol. 32. No. 7. 639-652. o. https://doi.org/10.1080/ 00343409850119526. 
Harrod, R. F. [1939]: An essay in dynamic theory. Economic Journal, Vol. 49. No. 193. 14-33. o. https://doi.org/10.2307/2225181.

Hermes, N.-Lensink, R. [2003]: Foreign direct investment, financial development and economic growth. Journal of Development Studies, Vol. 40. No. 1. 142-163. o. https://doi.org /10.1080/00220380412331293707.

Herzer, D. [2012]: How does foreign direct investment really affect developing countries' growth? Review of International Economics, Vol. 20. No. 2. 396-414. o. https://doi. org/10.1111/j.1467-9396.2012.01029.x.

Herzer, D.-Hühne, P.-Nunnenkamp, P. [2014]: FDI and income inequality - Evidence from Latin American economies. Review of Development Economics, Vol. 18. No. 4. 778-793. o. https://doi.org/10.1111/rode.12118.

Hughes, H. [1979]: Debt and development: The role of foreign capital in economic growth. World Development, Vol. 7. No. 2. 95-112. o. https://doi.org/10.1016/0305-750x(79)90026-3.

Hunya GÁвor [2014]: Regional Policy and FDI Location - An Overview of the Larger New EU Member States. WIIW Research Reports, No. 393.

IWASA KI, I.-ToKUnAGA, M. [2014]: Macroeconomic Impacts of FDI in Transition Economies: A Meta-Analysis. World Development, Vol. 61.53-69. o. https://doi.org/10.1016/j.worlddev. 2014.03.022.

Jensen, C. [2006]: Foreign Direct Investment and Economic Transition: Panacea or Pain Killer? Europe-Asia Studies, Vol.58. No. 6. 881-902. o. https://doi.org/10.1080/09668130600831084.

Johnson, A. [2006]: The effects of FDI on host country economic growth. Working Paper, No. 58. Royal Institute of Technology, Centre of Excellence for Studies in Science and Innovation, Stockholm.

Jones, J.-Wren, C. [2016]: Foreign Direct Investment and the Regional Economy. Routledge, London, https://doi.org/10.4324/9781315582764.

Kalotay Kálmán [2010]: Patterns of inward FDI in economies in transition. Eastern Journal of European Studies, Vol. 1. No. 2.55-76. o. http://ejes.uaic.ro/articles/EJES2010_0102_ KAL.pdf.

Kentor, J. [1998]: The Long-Term Effects of Foreign Investment Dependence on Economic Growth, 1940-1990. American Journal of Sociology, Vol. 103. No. 4. 1024-1046. o. https:// doi.org/10.1086/231295.

KóNYA IsTváN [2015]: Több gép vagy nagyobb hatékonyság? Növekedés, tőkeállomány és termelékenység Magyarországon 1995-2013 között. Közgazdasági Szemle, 62. évf. 11. sz. 1117-1139. o. https://doi.org/10.18414/ksz.2015.11.1117.

Lane, P. R.-Milesi-Ferretti, G. [2007]: Capital flows to central and Eastern Europe. Emerging Markets Review, Vol. 8. No. 2. 106-123. o. https://doi.org/10.1016/j.ememar.2007.01.004.

LAnkes, H. P.-Venables, A. J. [1996]: Foreign direct investment in economic transition: the changing pattern of investments. Economics of Transition, Vol. 4. No. 2. 331-347. o. https:// doi.org/10.1111/j.1468-0351.1996.tb00176.x.

Lengyel ImRe-VARGA AtTila [2018]: A magyar gazdasági növekedés térbeli korlátai - helyzetkép és alapvető dilemmák. Közgazdasági Szemle, 65. évf. 5. sz. 499-524. o. https://doi. org/10.18414/ksz.2018.5.499.

LIPSEY, R. E. [2000]: The role of foreign direct investment in international capital flows. NBER Working Paper, No. 7094. https://doi.org/10.3386/w7094.

Lucas, R. E., JR. [1988]: On the Mechanics of Economic Development, Journal of Monetary Economics, Vol. 22. No. 1. 3-42. o. https://doi.org/10.1016/0304-3932(88)90168-7. 
LuCAs, R. E., JR. [1990]: Why doesn't capital flow from rich to poor countries? American Economic Review, Vol. 80. No. 2. 92-96. o. http://www.jstor.org/stable/2006549.

Lux GÁвоR [2017a]: A külföldi működőtőke által vezérelt iparfejlődési modell és határai Közép-Európában. Tér és Társadalom, 31. évf. 1. sz. 30-52. o. https://doi.org/10.17649/ TET.31.1.2801.

Lux GÁBor [2017b]: Újraiparosodás Közép-Európában. Dialóg Campus Kiadó, Budapest-Pécs.

McCann, P. [1997]: How deeply embedded is Silicon Glen? A Cautionary Note. Regional Studies, Vol. 31. No. 7. 695-703. o. https://doi.org/10.1080/00343409750130777.

Mencinger, J. [2003]: Does foreign direct investment always enhance economic growth? Kyklos, Vol. 56. No. 4. 491-508. o. https://doi.org/10.1046/j.0023-5962.2003.00235.x.

Mileva, E. [2008]: The impact of capital flows on domestic investment in transition economies. Frankfurt am Main, European Central Bank, Working Paper, No. 871. https://www. ecb.europa.eu/pub/pdf/scpwps/ecbwp871.pdf?2b55011b65aa607223558182fa4f13f7.

NARula, R.-Guimón, J. [2010]: The investment development path in a globalised world: implications for Eastern Europe. Eastern Journal of European Studies, Vol. 1. No. 2. 5-19. o.

Neuhaus, M. [2006]: Impact of FDI on Economic Growth. An Analysis for the Transition Countries of Central and Eastern Europe. Springer, 155 o.

Nölke, A.-Vliegenthart, A. [2009]: Enlarging the varieties of capitalism: The emergence of dependent market economies in East Central Europe. World Politics, Vol. 61. No. 4. 670-702. o. https://doi.org/10.1017/s0043887109990098.

OlofSDotTer, K. [1998]: Foreign direct investment, country capabilities and economic growth. Weltwirtschaftliches Archiv, Vol. 134. No. 3. 534-547. o. https://doi.org/10.1007/bf02707929.

Pavlinek, P. [2004]: Regional development implications of foreign direct investment in central Europe. European Urban and Regional Studies, Vol. 11. No. 1. 47-70. o. https://doi. org/10.1177/0969776404039142.

Prasad, E. S.-Rajan, R. G.-Subramanian, A. [2008]: Foreign capital and economic growth. Brookings Papers on Economic Activity, No. 1. 153-230. o. https://doi.org/10.1353/ eca.2007.0016.

Raviv, O. [2008]: Chasing the Dragon East: Exploring the Frontiers of Western European Finance. Contemporary Politics, Vol. 14. No. 3. 297-314. o. https://doi.org/10.1080/ 13569770802396345.

Reisen, H.-Soto, M. [2001]: Which types of capital inflows foster developing country growth? International Finance, Vol. 4. No. 1. 1-14. o. https://doi.org/10.1111/1468-2362.00063.

RodríGuez-Pose, A. [1998]: Social conditions and economic performance: The bond between social structure and regional growth in Western Europe. International Journal of Urban and Regional Research, Vol. 22. No. 3. 443-459. o. https://doi.org/10.1111/1468-2427.00151.

Romer, P. M. [1990]: Endogenous technological change. Journal of Political Economy, Vol. 98. No. 5. 71-102. o. https://doi.org/10.1086/261725.

Rostow, W. W. [1959]: The stages of economic growth. Economic History Review, Vol. 12. No. 1. 1-16. o. https://doi.org/10.1111/j.1468-0289.1959.tb01829.x.

RugrafF, E. [2010]: Strengths and weaknesses of the outward FDI path of the Central European countries. Post Communist Economies, Vol. 22. No. 1. 1-17. o. https:/doi. org/10.1080/14631370903525561.

Schmidt Andrea [2014]: The Economic Transformation in Hungary - Detour or Impasse. Politeja, Vol. 11. No. 28. 115-138. o. https://doi.org/10.12797/politeja.11.2014.28.05.

Schmidt Andrea [2015]: International Political Economy. The Visegrad 4 States and the Economic Transformation. University of Pécs, Department of Political Science, Pécs. 
Skersan-Skabic, I.-Tijanic, L. [2014]: The Influence of Foreign Direct Investments on Regional Development in Croatia. Croatian Economic Survey, Vol. 16. No. 2. 59-90. o. https://doi.org/10.15179/ces.16.2.3.

Solow, R. [1957]: Technical change and the aggregate production function. Review of Economics and Statistics, Vol. 39. No. 3. 312-320. o. https://doi.org/10.2307/1926047.

Te Velde, D. W. [2001]: Government policies towards inward foreign direct investment in developing countries: Implications for human capital formation and income inequality. FDI, human capital and education in developing countries. Technical Meeting, OECD Development Centre, Párizs.

Todaro, M.-Smith, S. [2012]: Economic Development. Pearson, 860 o.

Turkcan, B.-Duman, A.-Yetkiner, I. H. [ 2008]: How does FDI and economic growth affect each other? The OECD case. International Conference on Emerging Economic Issues in a Globalizing World. Izmir, május 25. https://core.ac.uk/download/pdf/6989913.pdf. 